\title{
ATMOSPHERIC BOUNDARY LAYER MEASUREMENTS DURING SUMMER MONEX 79 AT DIGHA, INDIA
}

\author{
S. SethuRaman, P. Michael, \\ W.A. TUTHILL, AND J. MCNEIL
}

November 1979

DEPARTMENT OF ENERGY AND ENVIRONMENT

BROOKHAVEN NATIONAL LABORATORY UPTON, NEW YORK 11973 


\section{DISCLAIMER}

This report was prepared as an account of work sponsored by an agency of the United States Government. Neither the United States Government nor any agency Thereof, nor any of their employees, makes any warranty, express or implied, or assumes any legal liability or responsibility for the accuracy, completeness, or usefulness of any information, apparatus, product, or process disclosed, or represents that its use would not infringe privately owned rights. Reference herein to any specific commercial product, process, or service by trade name, trademark, manufacturer, or otherwise does not necessarily constitute or imply its endorsement, recommendation, or favoring by the United States Government or any agency thereof. The views and opinions of authors expressed herein do not necessarily state or reflect those of the United States Government or any agency thereof. 


\section{DISCLAIMER}

Portions of this document may be illegible in electronic image products. Images are produced from the best available original document. 


\title{
ATMOSPHERIC BOUNDARY LAYER MEASUREMENTS DURING SUMMER MONEX 79 AT DIGHA, INDIA
}

\author{
S. SethuRaman, P. Michael, W.A. Tuthill, and J. McNeil
}

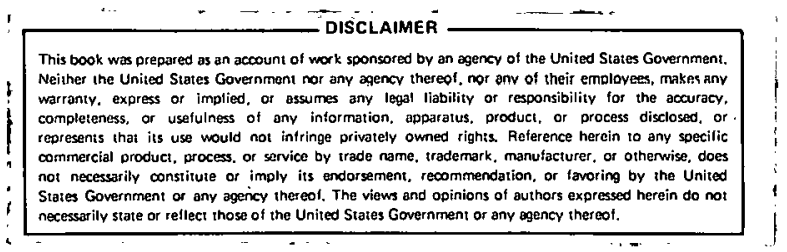

\author{
ATMOSPHERIC SCIENCES DIVISION \\ DEPARTMENT OF ENERGY AND ENVIRONMENT \\ BROOKHAVEN NATIONAL LABORATORY \\ ASSOCIATED UNIVERSITIES, INC.
}

UNDER CONTRACT NO. DE-AC02-76CH00016 WITH THE UNITED STATES DEPARTMENT OF ENERGY 


\section{DISCLAIMER}

This book was prepared as an account of work sponsored by an agency of the United Sitates Liovernment. Neither the United States Covernmeno intr any nypully ilirı ruf, nor any of their employees, makes any warranty, express or implied, or assumes any legal liability or responsibility for the accuracy, completeness, or usefulness of any information, apparatus, product, or process disclosed, or represents that its use would not infringe privately owned rights. Reference herein to any specific commercial product, process, or service by trade name, trademark, manufacturer, or otherwise, does not necescarily constitute or imply its endorsement, rerommentation, or favoring hy the United States Government or any agency thereof. The views and opinions of authors expressed herein do not necessarily state or reflect those of the United States Government or any agency thereof.

Printed in the United States of America Available from

National Technical Information Service

U.S. Department of Commerce 5285 Port Royal Road

Springfield, VA 22161

Price: Printed Copy $\$ 4.50$; Micrufiche $\$ 3.00$ 


\section{ABSTRACT}

Marine boundary layer experiments conducted over the Bay of Bengal at Digha beach, West Bengal, India, as part of the International Monsoon Experiments (MONEX 79) are described in this paper. The experiments consisted of measurements of atmospheric turbulence and fluxes of momentum, heat, and water vapor from a 10-m-high coastal meteorological tower. Mean meteorological parameters were measured with an automated electronic weather station. Wind speed and direction profiles were obtained with pilot balloon soundings. Some typical tropical meteorological features photographed during the experiment are also presented. 


\section{THIS PAGE \\ WAS INTENTIONALLY \\ LEFT BLANK}




\section{CONTENTS}

Abstract . . . . . . . . . . . . . . . . . . . . . . . iii

Introduction . . . . . . . . . . . . . . . . . . . . . . . 1

Measurements . . . . . . . . . . . . . . . . . . . . 5

Synoptic Conditions . . . . . . . . . . . . . . . . . . . . 12

Ro11 Clouds, Waterspouts,
and Convective Cells... . . . . . . . . . . . . . . . . . 18

Data Analysis . . . . . . . . . . . . . . . . . . . . . 18

Acknowledgments . . . . . . . . . . . . . . . . . . . . . . 23

References . . . . . . . . . . . . . . . . . . . . . 23

Appendix I

Surface Weather Maps . . . . . . . . . . . . . . . . 26 


\section{INTRODUCTION}

The importance of the monsoons as a major energy source for the global circulation of the atmosphere has long been recognized. The seasonally varying circulations associated with the heating and cooling of Asia-EuropeAfrica complex is most important, although poorly understood. Monsoon rainfall, which varies in timing and amount from year to year, affects the agriculture and economy of hundreds of millions of people. Prediction of monsoon strengths is virtually impossible without knowledge of the large-scale seasonal monsoon circulations.

In order to understand these processes, a. Monsoon Sub-Programe was developed as part of the Global Atmospheric Research Programme (GARP) of the World Meteorological Organization (WMO). It consisted of a coordinated group of observational studies and associated data processing. The central field experiment of the Monsoon Sub-Programme was the Monsoon Experiment (MONEX), which consisted of a group of observational studies during the period of the First GARP Global Experiment (FGGE) over the Arabian Sea, Indian Ocean, Bay of Bengal, and Southeast Asia.

An important synoptic component of the Indian southwest monsoon is the monsoon depressions that form in the Bay of Bengal. The surface pressure trough or the "monsoon trough" over the Indian subcontinent is oriented northwest-southeast in summer lying south of and roughly parallel to the Himalayas along the Gangetic plains. Monsoon depressions form near the eastern end of the trough, over the northern Bay of Bengal, and move inland slowly losing their strength. These depressions covering an area of about five degrees latitude-longitude square often persist for a week or more over land causing very heavy rain, both widespread and locally.l The depressions do not generally acquire hurricane intensity, probably for two reasons ${ }^{2}$ : (1) they do not stay over the ocean long enough to gain strength, and (2) the presence of large vertical wind shear due to monsoon westerlies at low levels and strong easterlies at upper levels inhibits accumulation of latent heat.

The structure of the depressions has been investigated in the past, $3-7$ but these studies were done after the depressions moved inland where upper air observations were available. One of the main objectives of the summer monsoon experiments (MONEX 79) was to study the monsoon depressions over the Bay of Bengal with instrumented aircraft and ships in addition to ground stations. The marine boundary layer experiment described in this paper was conducted by the Atmospheric Sciences Division of the Brookhaven National Laboratory (BNL) to supplement aircraft observations and provide information regarding the air-sea interaction processes responsible for cyclogenesis over the Bay of Bengal.

The experiments were conducted at Digha, West Bengal, India, located at $21^{\circ} 30^{\prime} \mathrm{N}$ and about $88^{\circ} \mathrm{E}$ (Figure 1). Several sites along the coast between $16^{\circ} \mathrm{N}$ and $22^{\circ} \mathrm{N}$ were considered, and Digha was selected because of its flat beach with predominant onshore winds in summer and its location in the mean storm track of the depressions. 1 A view of the beach is shown in Figure 2 , and storm tracts based on data recorded for the month of July over a period of about 70 years are shown in Figure 3. Digha was also one of the upper-air radiosonde stations of the Indian Meteorological Department during June, July, and August 1979. 


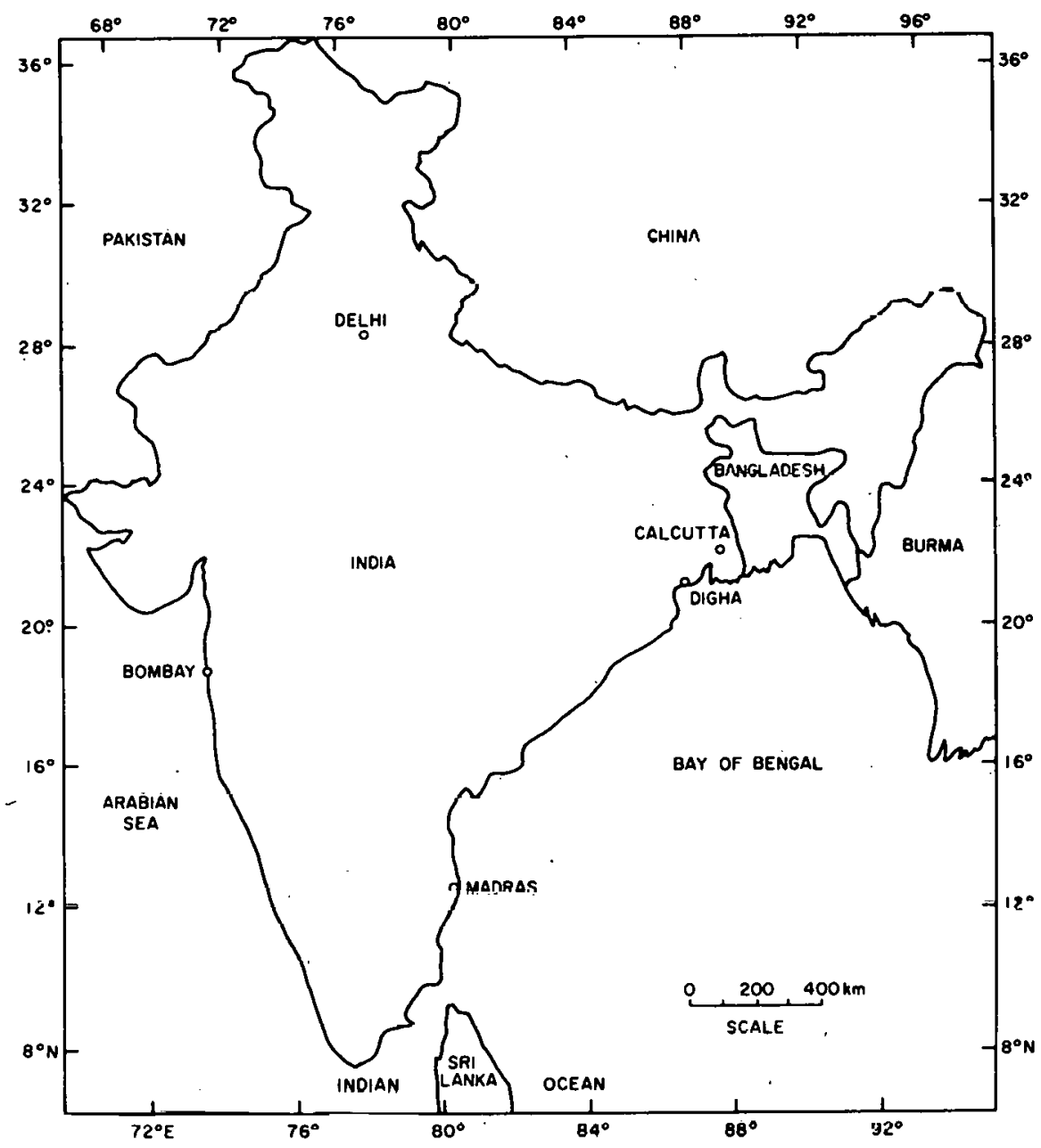

Figura 1. Mop shnwing the loçation of Digha on the coast of Bay of Bengal. 


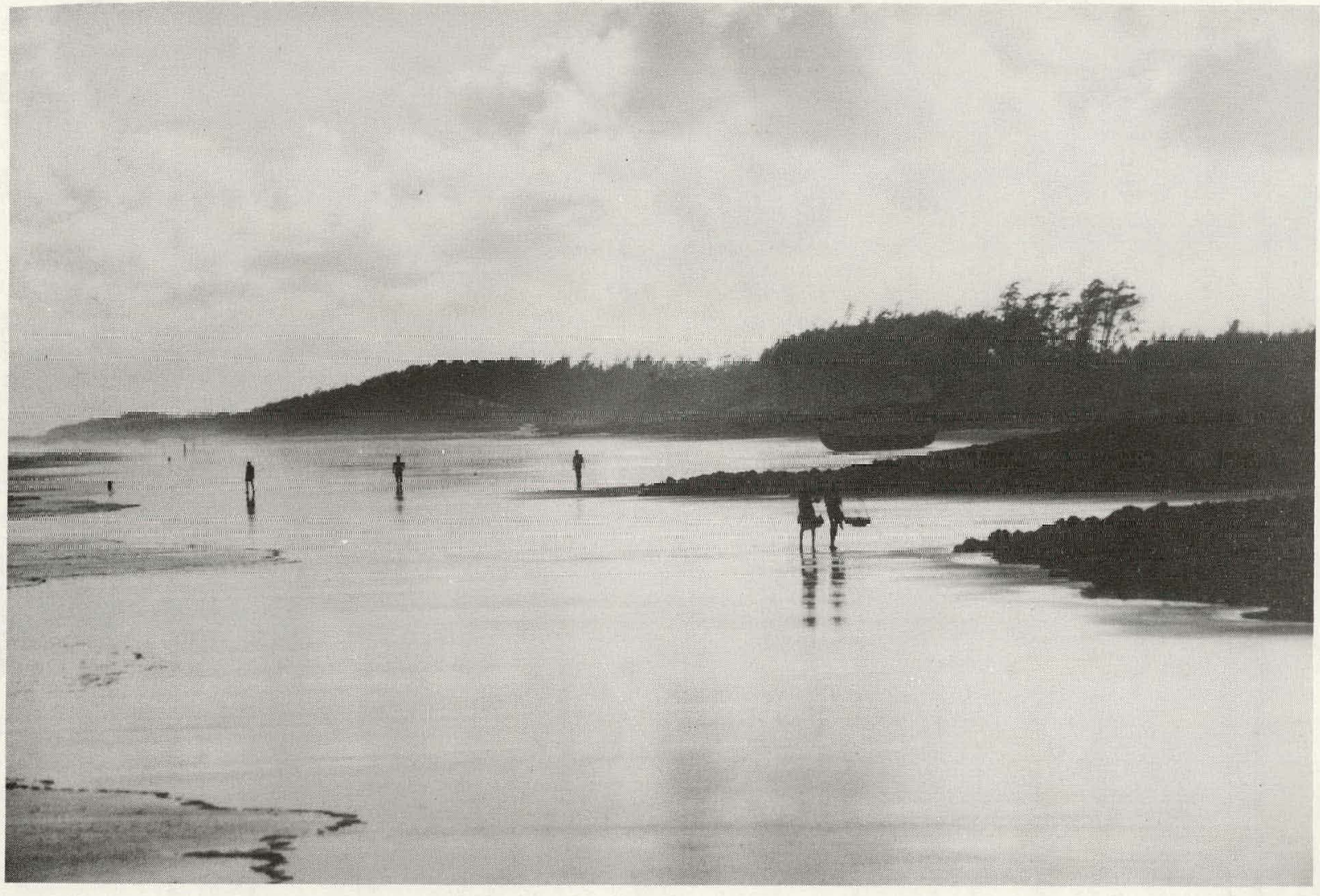

Figure 2. A view of the beach at Digha. 


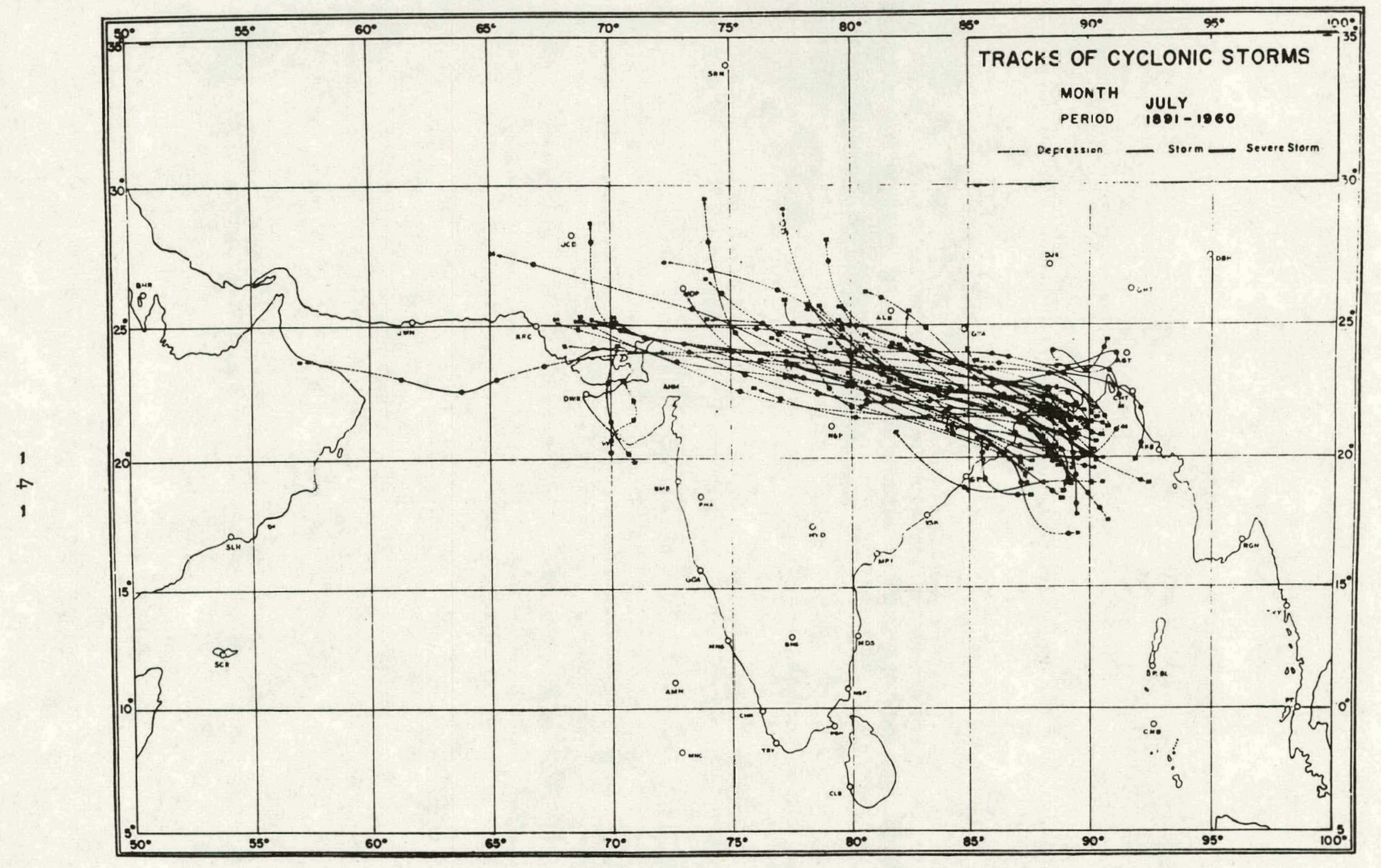

Figure 3. Stcrm tracks for the month of July based on data for 70 years (after Rao, 1976). 
The boundary layer experiment at Digha consisted of

a. A 10-m micrometeorological tower at the beach with instruments to observe turbulent fluxes over the ocean.

b. A weather station that continuously recorded mean parameters.

c. Pilot balloon observations to a height of about $1000 \mathrm{~m}$.

Details of measurements and data acquisition for each of the components are described in the following paragraphs.

The meteorological tower at the beach consisted of three 3-m aluminum tower sections erected one over the other to a height of about $10 \mathrm{~m}$ from the base. The foundation for the tower consisted of the platform of an abandoned navigation light post. The top of the platform was about $2.5 \mathrm{~m}$ above the beach, and the difference between low and high tides at Digha was about $2 \mathrm{~m}$. The base of the tower was secured to the concrete platform with expansion bolts and supported by four guy wires attached to pilings driven into sand. A photograph of the tower at the beach is shown in Figure 4. The instruments mounted on the tower measured mean wind speeds at four levels and turbulence components at a height of $10 \mathrm{~m}$ above the base. Actual height to the instrument positions was estimated from the observations of low and high tide levels. Deployment of the instruments at the tower is indicated by a line diagram in Figure 5. The instruments used were similar to the ones used by BNL at air-sea interaction experiments over the Atlantic Ocean. ${ }^{8}$ A close-up view of the instruments at $10 \mathrm{~m}$ that measured longitudinal, lateral, and vertical velocity fluctuations and temperature and humidity fluctuations is shown in Figure 6.

Mean wind profiles were obtained with a vertical array of cup anemometers. These anemometers were designed and fabricated at BNL and used photo transistor light chopper transducers to increase their response. Their response distance is about $1 \mathrm{~m}$, thus making it possible to obtain a reasonably good estimate of longitudinal turbulence.

Turbulence sensors were mounted about $8 \mathrm{~m}$ above the base of the tower. Vertical velocity fluctuations were obtained with a Gill propeller anemometer (manufactured by R. M. Young Company). The propeller drives a miniature dc tachometer generator providing an analog output directly proportional to wind speed. The distance constant is estimated to be $0.8 \mathrm{~m}$. Vertical velocity fluctuations were also measured by a bidirectional vane designed and fabricated at BNL. The bivane consists of a vertical housing and a sensor assembly composed of a horizontally mounted tripod supporting an annular fin at its base. The electrical analog of vertical displacement is obtained via a lightweight chain running over a drum and down a hollow shaft to a linear displacement transducer giving a dc output. Response distance of the bidirectional vane in the vertical direction was estimated to be $0.78 \mathrm{~m}$. Design features and response tests of this vane have been described elsewhere. 9

Longitudinal component of the wind was measured by a vortex anemometer (manufactured by $\mathrm{J}-\mathrm{Tec}$ Assoclates, Inc.). A vortex wind speed sensor was mounted in the tail section of an aerodynamically shaped vane. In this sensor, a series of vortices are formed as the airstream passes a triangular 


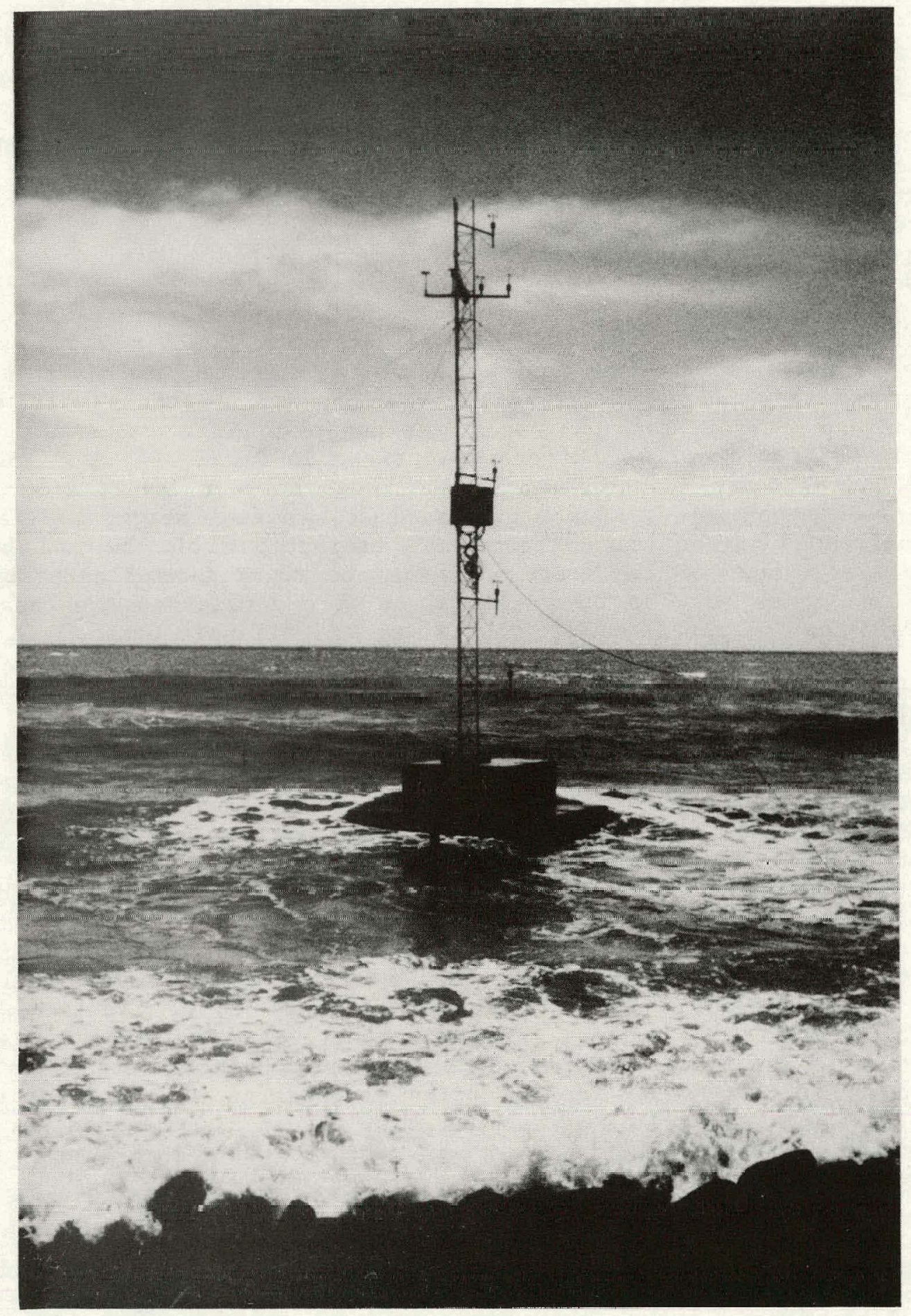

Figure 4. Instrumented meteorological tower at the beach. 


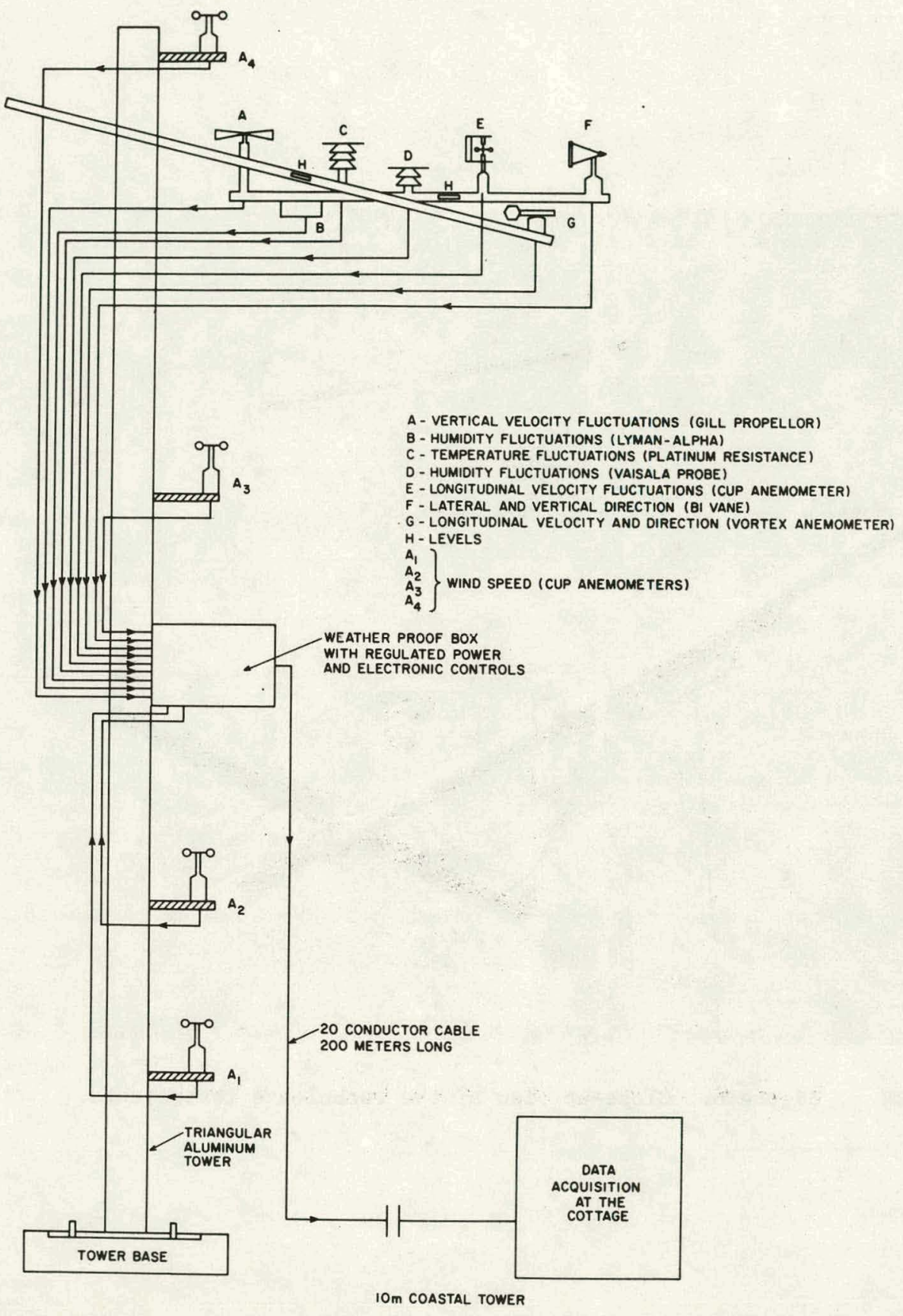

Figure 5. Line diagram showing the arrangement of the meteorological instruments and electronic control at the tower. 


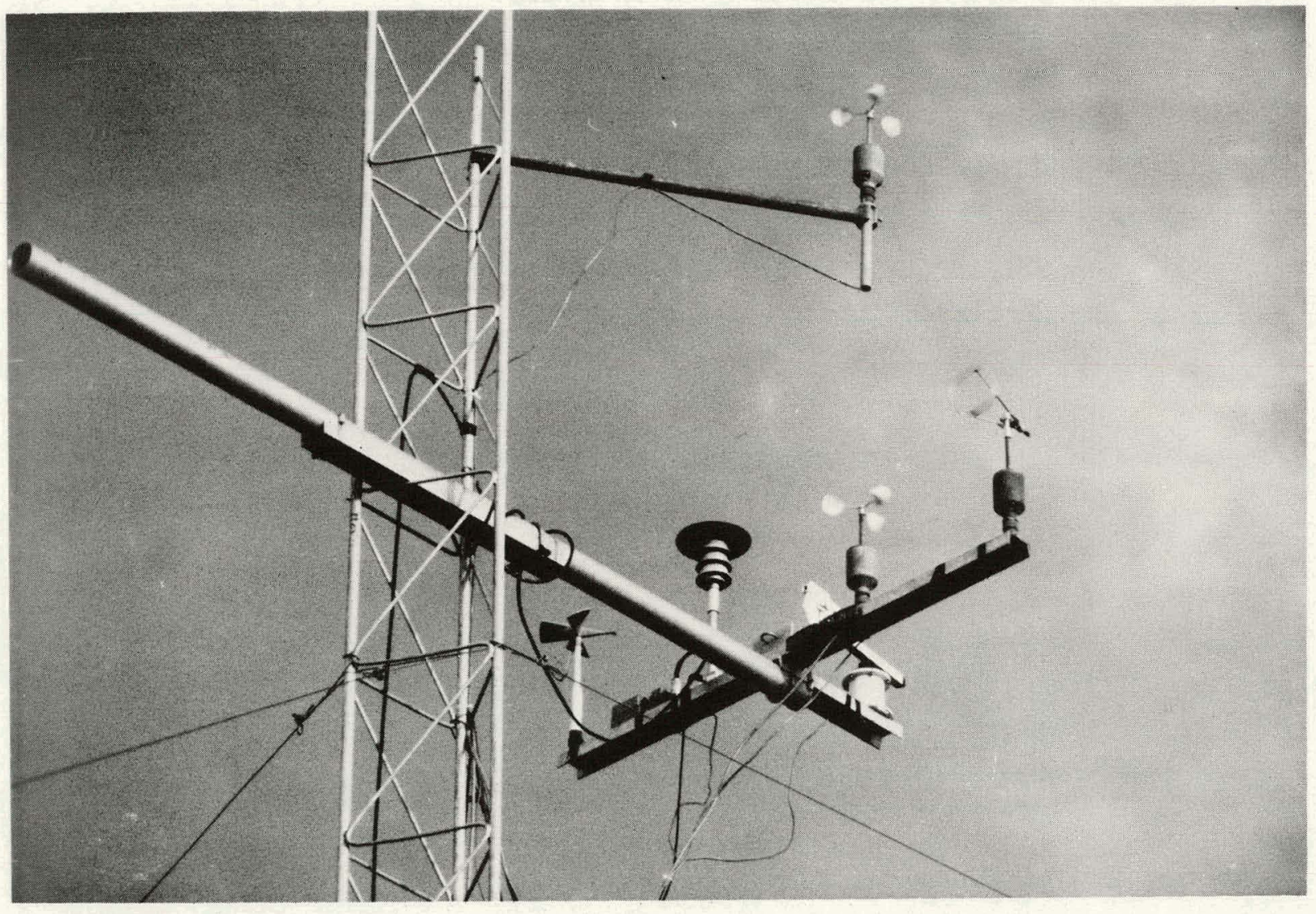

Figure 6. Close-up view of the turbulence instruments. 
rod. These vortices are sensed with an ultrasonic oscillator. The relationship between the vortex frequency and the wind speed as given by Strouhal number is used to determine velocity fluctuations. A distance constant of $0.1 \mathrm{~m}$ is estimated for velocity fluctuations. Longitudinal component of the wind speed was also measured by a miniature fast-response cup anemometer designed and fabricated at BNL (Figure 7). It consisted of three 1-cm plastic cups supported by a U-frame with point bearings and with a tail provided to keep it downwind. Wind tunnel tests indicated the response distance to be about $0.5 \mathrm{~m}$. Lateral component of wind was measured by the bidirectional vane. A small synchro was used to obtain the changes in wind direction in a horizontal plane, and the synchro output converted to dc sine and cosine values. The response distance of the bivane for horizontal directional fluctuations was found to be $1.25 \mathrm{~m}$. Changes in horizontal wind direction were also measured by the vane in the vortex anemometer. Its distance constant was about $5 \mathrm{~m}$.

Mean and fluctuating air temperatures were measured with a fast response temperature sensor consisting of a $12-\mu$ platinum wire and a Wheatstone bridge circuit (manufactured by Atmospheric Instruments Research, Inc.), having a sensitivity of $100 \mathrm{mV} /{ }^{\circ} \mathrm{C}$ and a frequency response of $10 \mathrm{~Hz}$ at wind speeds greater than $5 \mathrm{~m} \mathrm{sec}^{-1}$.

Mean and fluctuating atmospheric humidity were measured by a Lyman-Alpha humidity sensor (manufactured by Electromagnetic Research Corporation). The Lyman-Alpha radiation $(1215.6 \AA)$ is generated by a source tube, emerges from a uv window, crosses the measuring path, and enters the detector. The detector, also equipped with a uv window, is an ionization chamber filled with nitric oxide gas. The Lyman-Alpha radiation ionizes the nitric oxide in the detector, causing a current flow. At Lyman-Alpha range, the absorption coefficient of water vapor far exceeds that of the other gases. Thus the current generated is a measure of the water vapor content of the air in the measuring path. A logarithmic amplifier converts the exponential variation of output current with water vapor concentration into a linear relationship. The sensor has a high frequency response ( $>10 \mathrm{~Hz}$ ). Mean and fluctuating atmospheric humidity was also measured by a capacitance-type humidity sensor (manufactured by Weather Measure Corporation). The measurement technique is based upon the capacitance change of a polymer thin film capacitor. A 1- $\mu$-thick dielectric polymer layer absorbs water molecules through a thin metal electrode and causes capacitance change proportional to relative humidity. Response time is about $1 \mathrm{sec}$. The humidity sensors could not be operated continuously for periods in excess of a day because of tropical algae deposits. They had to be cleaned with distilled water periodically.

A weatherproof box installed on the tower housed a power regulator and electronic controls for the instruments (Figure 8). All the instruments were operated on $12-\mathrm{V}$ dc power and were designed to perform with low power. Maximum power consumption with all the instruments in operation was about $12 \mathrm{~W}$. In order to maintain a constant power supply to the instruments and to protect against the line losses, $24 \mathrm{~V}$ were sent through power cables and regulated to $12 \mathrm{~V}$ at the tower. Other electronic components in this weatherproof box consisted of $\pm 15-\mathrm{V}$ interfaces, active analog filters, and instrument controls. The power supply to, and analog outputs from, the instruments were carried to and from the tower respectively with a 200-m-1ong, 20 conductor cable. The line diagram in Figure 5 shows the interfacing through this junction box. 


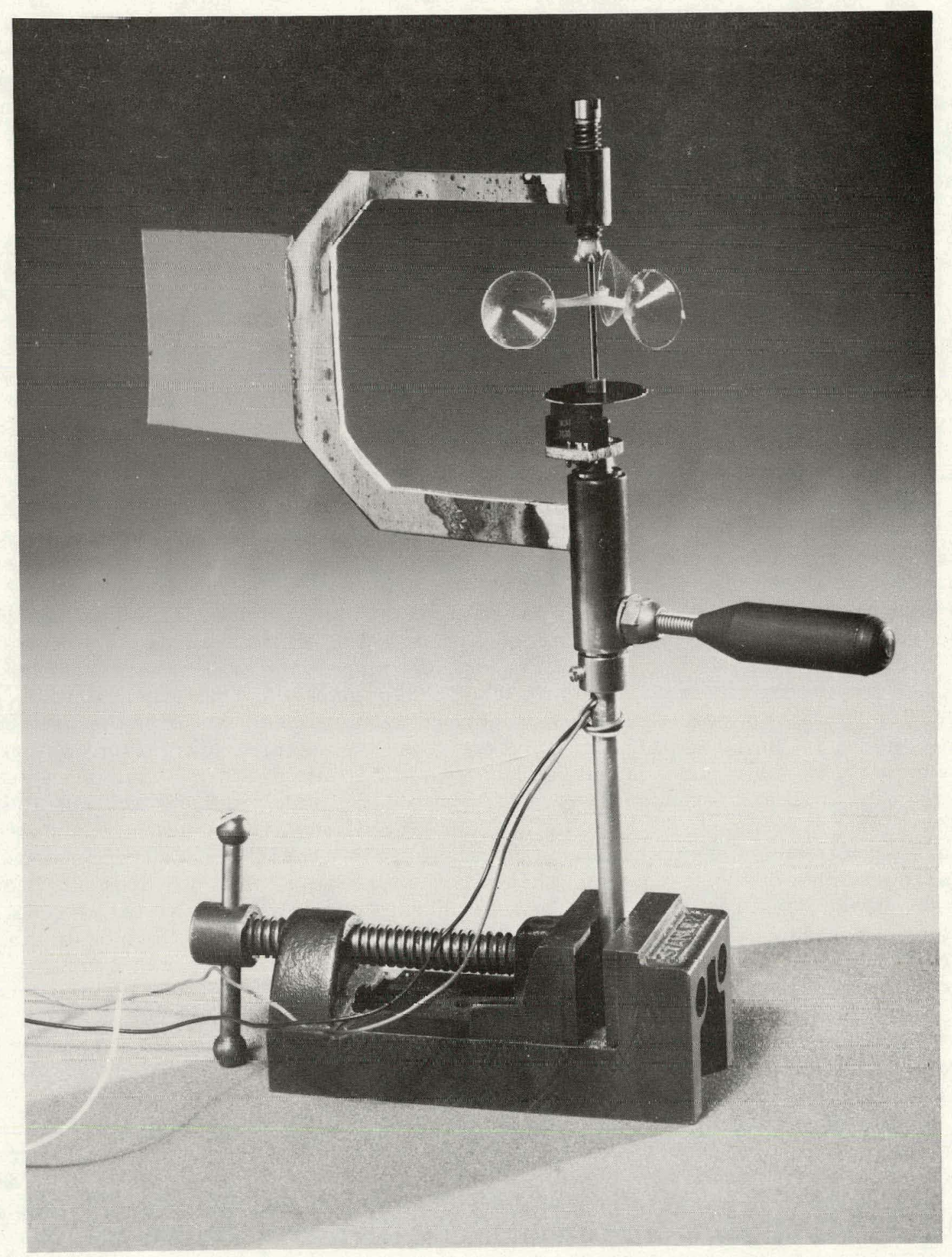

Figure 7. Fast-response cup anemometer. 


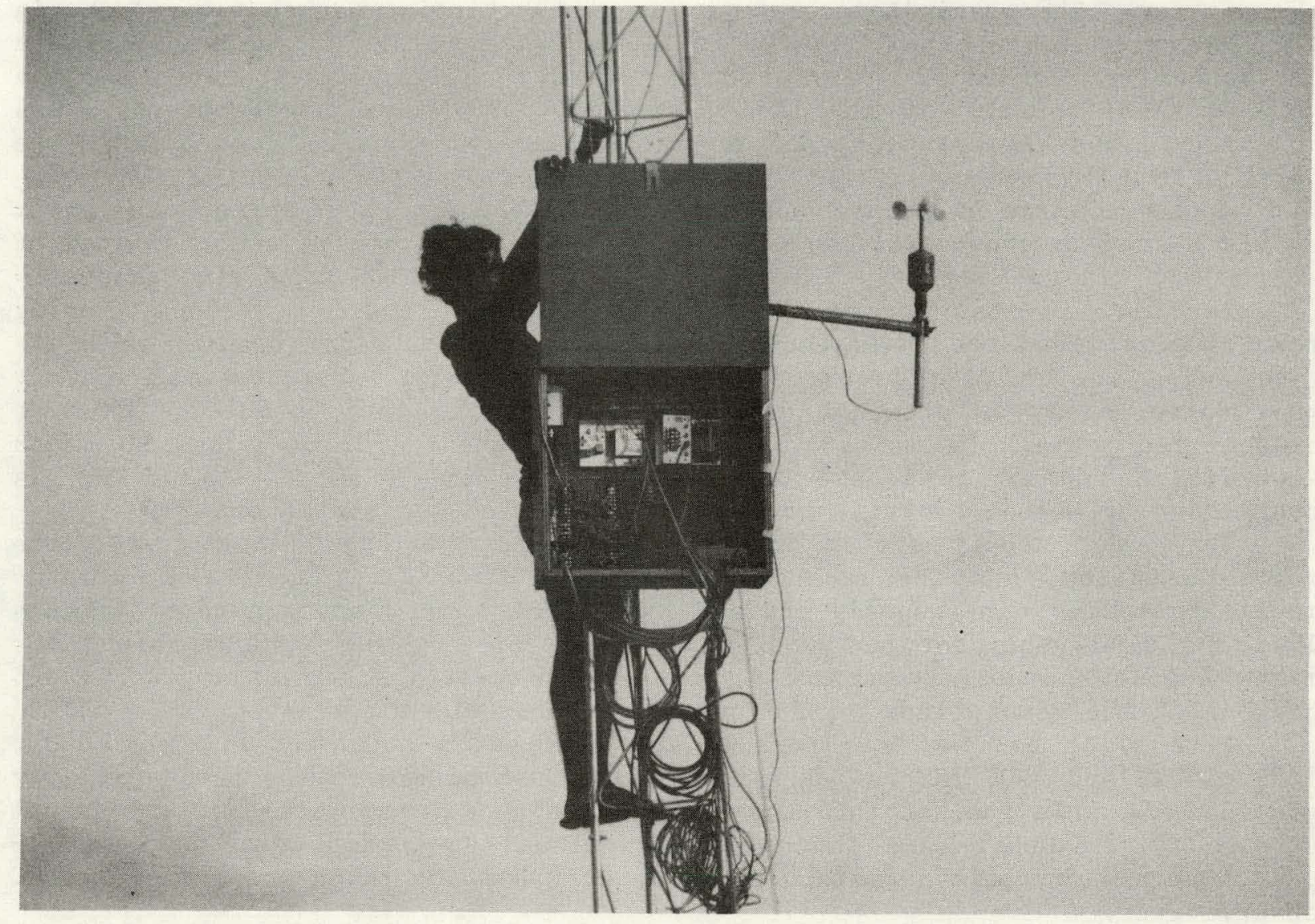

Figure 8. Weatherproof box with electronic controls and a power regulator. 
The power supply and data acquisition systems were housed in a two-room tourist cottage owned by the West Bengal Government and situated about $200 \mathrm{~m}$ inland from the beach (Figure 9). A weather station (manufactured by Climatronics, Inc.) with sensors to measure wind speed, direction, air temperature, dew point temperature, solar radiation, and precipitation was installed on the roof of the cottage at a height of about $10 \mathrm{~m}$ (Figure 10). A cup anemometer was used to measure the wind speed, a vane to measure direction and a thermistor for air temperature. Dew point temperature was obtained with a lithium chloride dewcell sensor and solar radiation with a silicon photovoltaic cell pyranometer. The precipitation gauge was of the tipping bucket type, each tip of the bucket being equal to 0.01 inches of water. All six parameters were continuously recorded by a strip chart recorder, and the instruments and the recorder were operated by the $12-\mathrm{V}$ dc power supply. Atmospheric pressure was measured with a capacitance-type pressure transducer (manufactured by Validyne Corporation).

A line diagram of the weather station, data acquisition system, and power supply system is shown in Figure 11. The data acquisition system consisted of analog and digital magnetic tape recorders that recorded data simultaneously (Figure 12). Digital recording was at the rate of two per second. Analog recording provided the advantage of obtaining original data that can be digitized at a faster rate during analysis, if necessary. The digital recorder was controlled by an external electronic timer to record turbulence data at preselected time intervals, thus ensuring round-the-clock automatic data acquisition. During periods of meteorological interest, the timer command was overridden by manual control and the data were recorded continuously.

The power supply system for the instruments at the beach tower, the weather station, and the recorders consisted of an array of six 12-V automobile batteries continuously charged by a 200-W wind power generator (Figure 10). The wind generator had a starting speed of $3 \mathrm{~m} \mathrm{sec}^{-1}$ and attained its maximum power capability around $10 \mathrm{~m} \mathrm{sec}^{-1}$, beyom which a spring activatcd brake kept the revolutions of the propeller constant.

Five pilot balloon soundings (Figure 13) taken each day at 0500, 0900, 1200,1600 , and 2000 IST to determine the wind structure in the boundary layer provided valuable insight into the boundary layer structure in similar coastal studies.10,11 Other data that were periodically recorded were sea temperature, wet and dry bulb temperatures taken with a sling psychrometer, and cloud observations.

\section{SYNOPTIC CONDTTTONS}

The weather station was operated for a month from July 4 to August 4 and the meteorological tower for 3 weeks from July 14 to August 3. Research aircrafts based in Calcutta were operational until the end of July. Available surface weather maps from June 26 to August 16,1979 are given in Appendix I. Unfortunately, no depressions formed between July 4 and August 4, the experiment period, but several low pressure systems did develop. Also, a tropical cyclone made landfall near Digha, just two days after the end of the experiment. Data collected during the last few days will be analyzed to look for any change in the air-sea interaction parameters associated with this cyclone. 


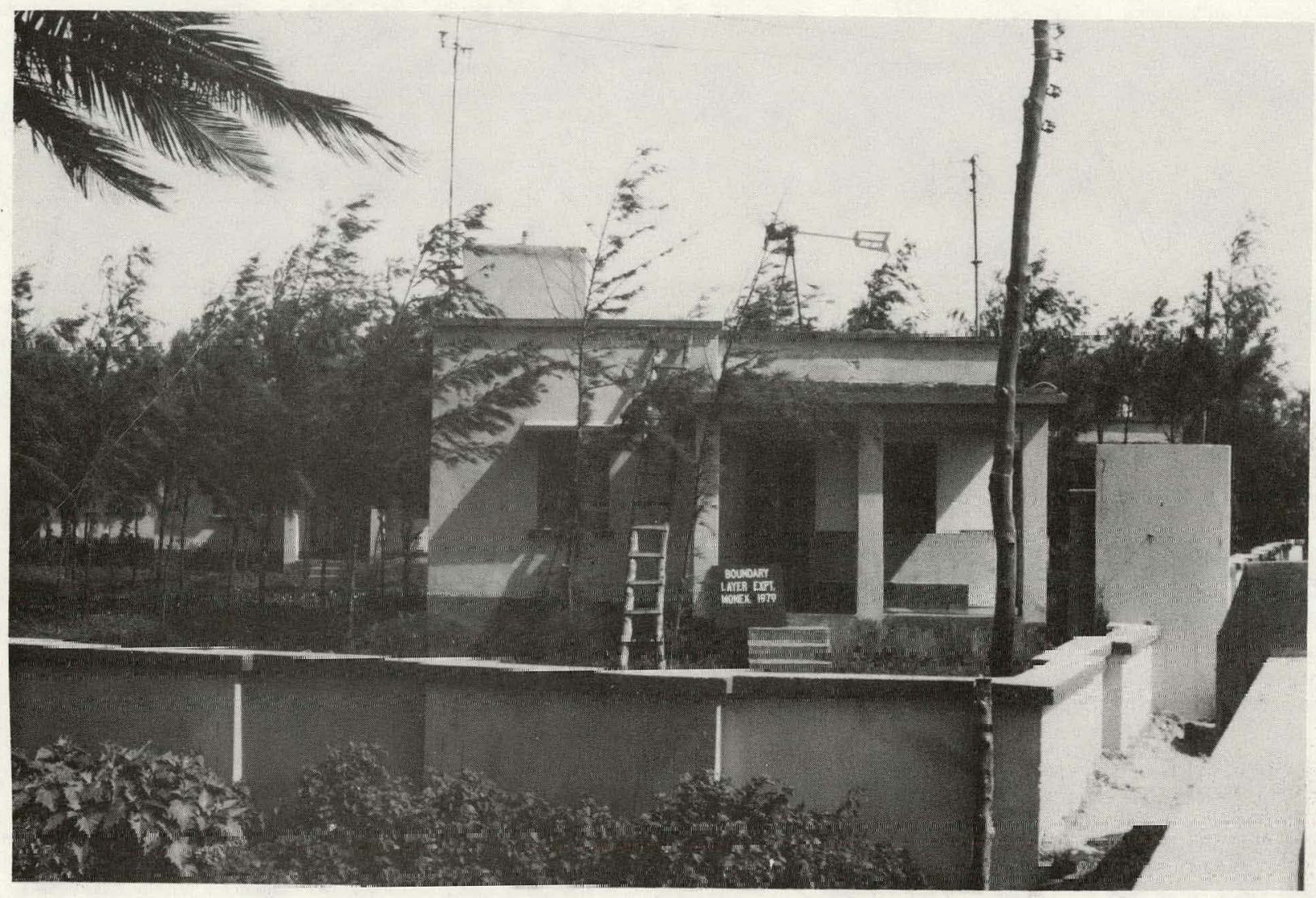

Figure 9. Tourist cottage where power supply and data acquisition system were housed. 


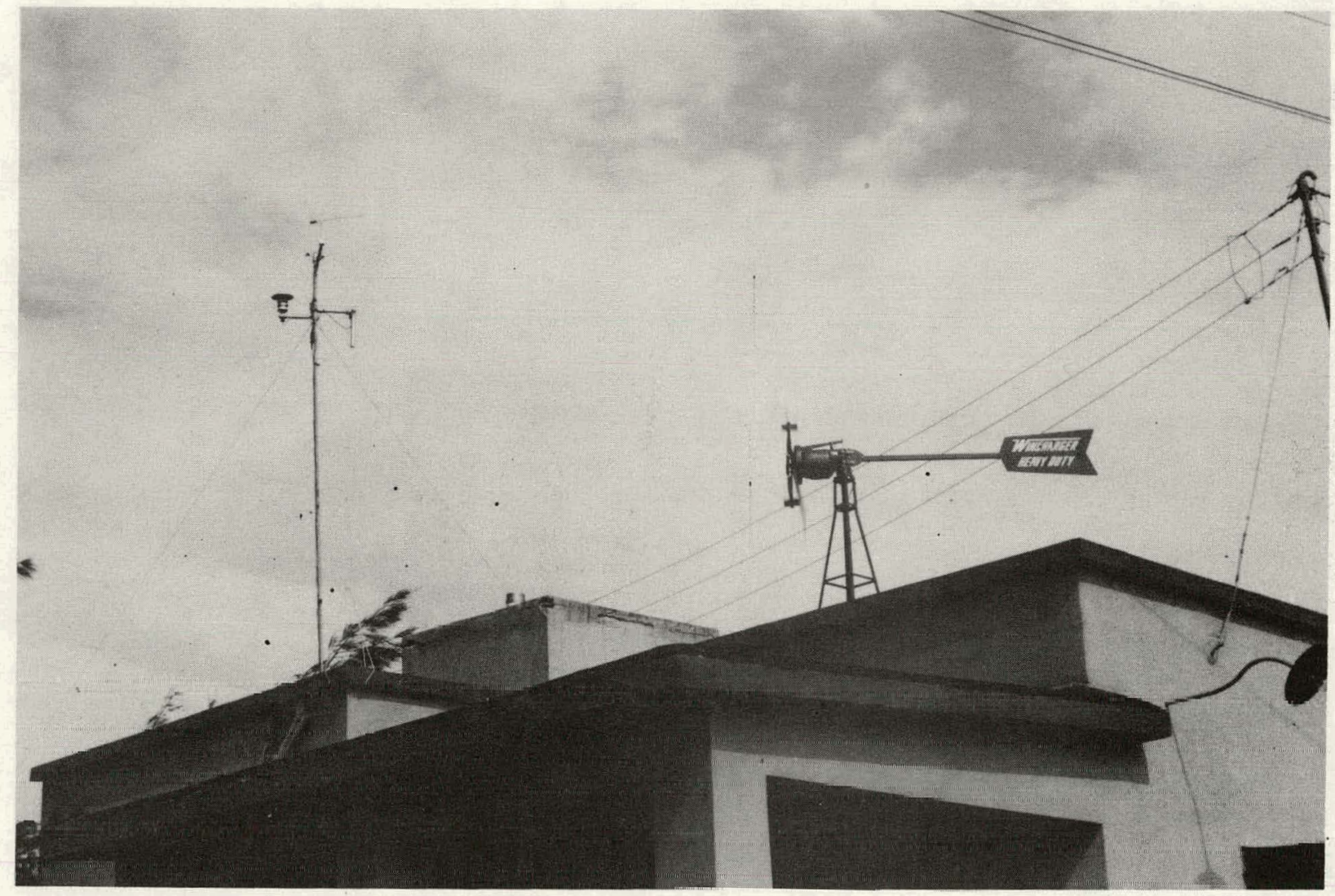

Figure 10. Weather station and wind power generator above the cottage. 


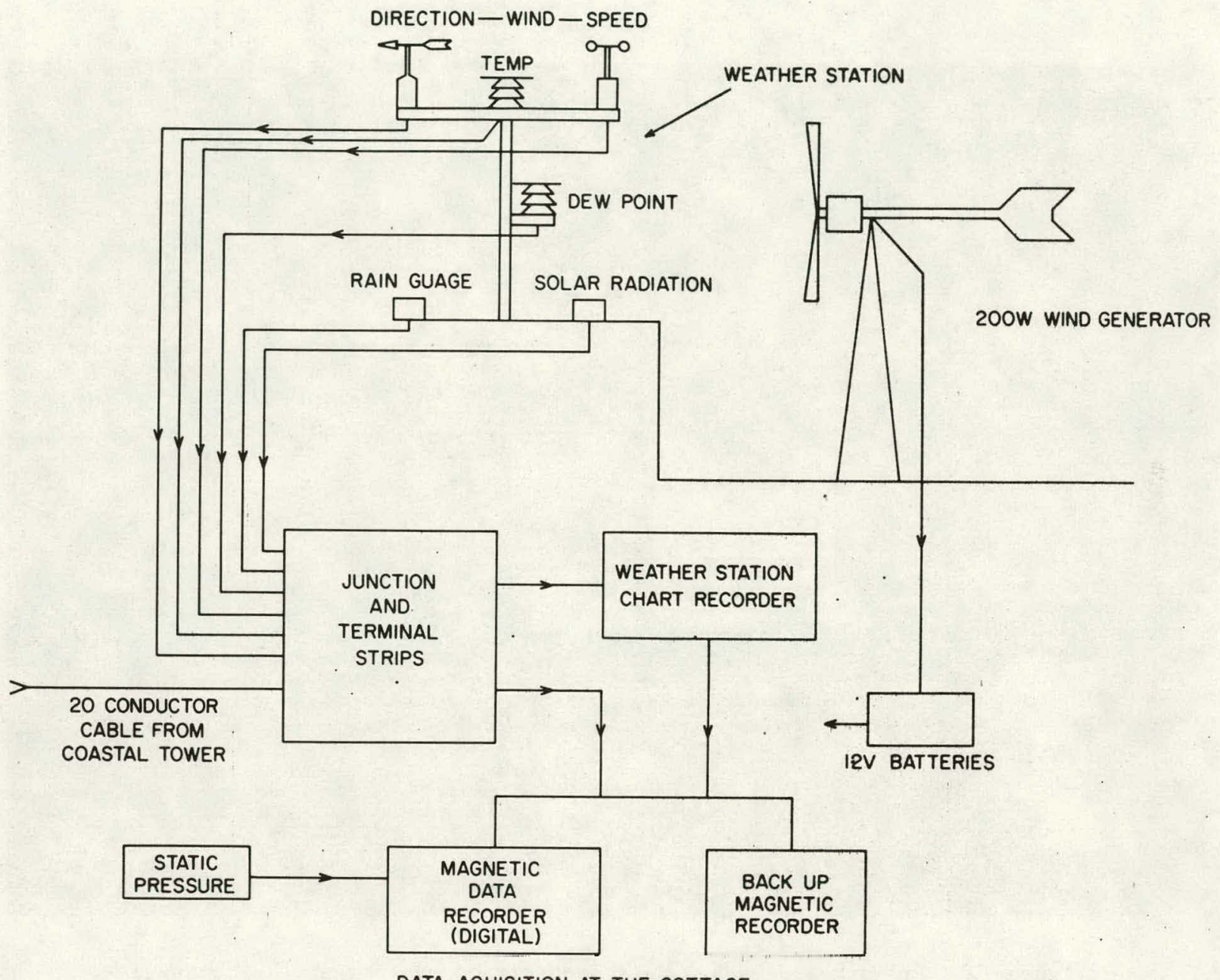

DATA AQUISITION AT THE COTTAGE

Figure 11. A line diagram showing the weather station, data acquisition system, and power supply system. 


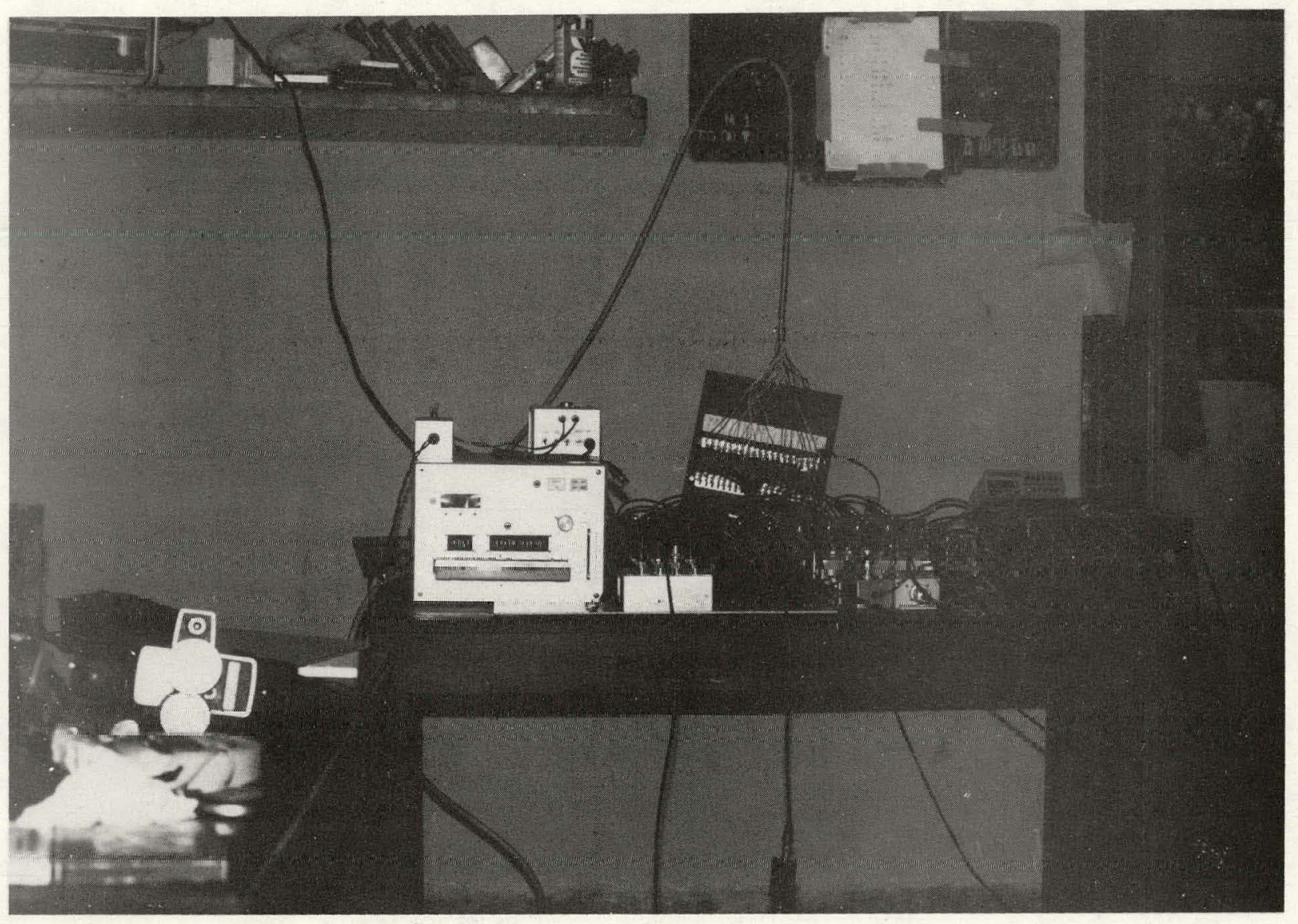

Figure 12. Primary and backup data acquisition systems at the cottage. 


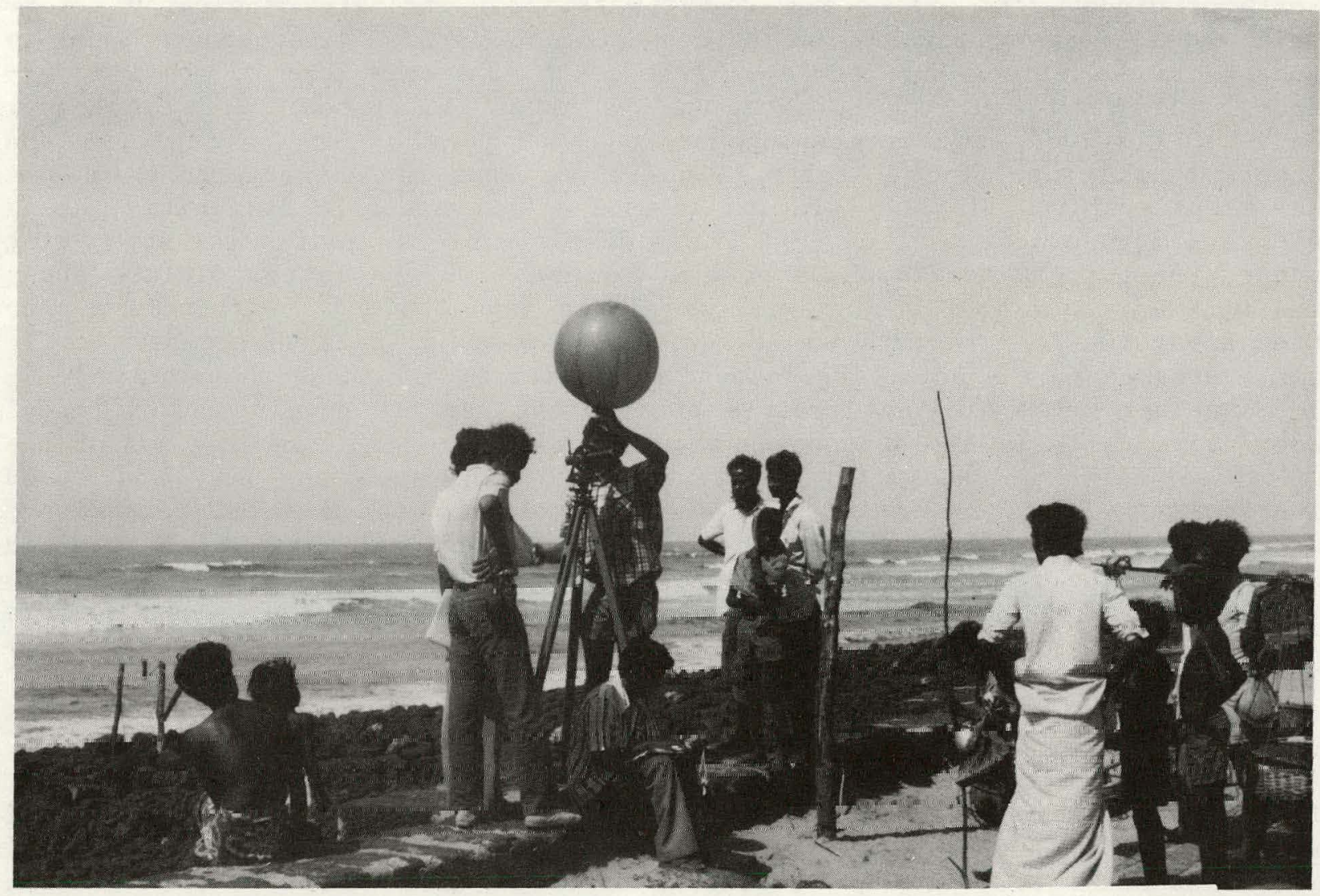

Figure 13. Pilot balloon sounding lin prugress at the beach. 
ROLL CLOUDS, WATERSPOUTS, AND CONVECTIVE CELLS

A band of roll clouds that appeared ahead of a monsoon depression is shown in Figure 14. This unique pattern of cloud formation was observed on June 29 near Digha. Synoptic conditions are indicated in the surface weather map in Appendix I.

Another observation of interest was of the waterspout activity over the Bay of Bengal on July 12 (Figure 15). A weak low pressure system was located south of Digha. The photograph of the waterspout indicates a clearly definable core. Sea surface temperature was about $31^{\circ} \mathrm{C}$. Water-spouts seem to undergo five discrete but overlapping stages ${ }^{12}$ : the dark spot on the sea surface, spiral pattern, the spray ring, the mature waterspout, and the decay. Golden ${ }^{12}$ observed some waterspouts to go through all the above stages and others bypass some of the stages. Figure 15 shows three photographs taken a few minutes apart. The top picture shows Llie waterspout in its initial stage with a lengthening funnel cloud. The middle picture indicates the spray ring stage, the primary growth phase of the vortex. And the bottom picture shows the matured waterspout with a well developed funnel cloud. Within five minutes after the last picture was taken, the waterspout decayed abruptly as it was overtaken by the advancing rainshower (shown in all three photographs).

Another meteorological feature of interest was the development of local convective cells in the afternoons with shower activity. A photograph of one of these cells is shown in Figure 16. During such periods wind speed increased by a factor of 5 , and air temperature and dewpoint temperature decreased by about $3^{\circ}$ to $4^{\circ} \mathrm{C}$ indicating intense vertical mixing. A detailed analysis of the meteorological parameters associated with these cells will be the subject of another paper. As an indicator of the predominant onshore winds at Digha, the shape of the palm trees is also worth noting (Figure 16). These trees would have an index of about 4 to 5 in the Griggs-Putnam index 13 ( $G$ index) of wind deformation which has a scale from 0 to 7 . The high index for Digha is probably due to its location with regard to the storm track (Figure 3 ) and the general southwesterly tlow direction during lhe munsoon. The characteristic most highly correlated with this index is the mean annual wind speed. G index seems to predict this wind speed within $15 \%$. The annual mean wind speed for Digha was estimated to be between 6 and $7 \mathrm{~m} \mathrm{sec}-1$ from a relationship given by Wade and Hewson. 14

\section{DATA ANALYSIS}

Mean, variance and turbulent fluxes are being computed for the duration of the experiment at Digha. Pilot balloon suundings are used to obtain the variation of wind speed and dirertion in the atmospheric boundary layer. Typical wind speed and direction profiles derived from one of the soundings are shown in Figure 17. An example of the time histories of turbulence, temperature, and humidity fluctuations are given in Figure 18. It is hoped that the boundary layer data being analyzed at BNL will contribute toward a better understanding of the ocean-atmosphere interaction proccsses over the Bay of Bengal. 


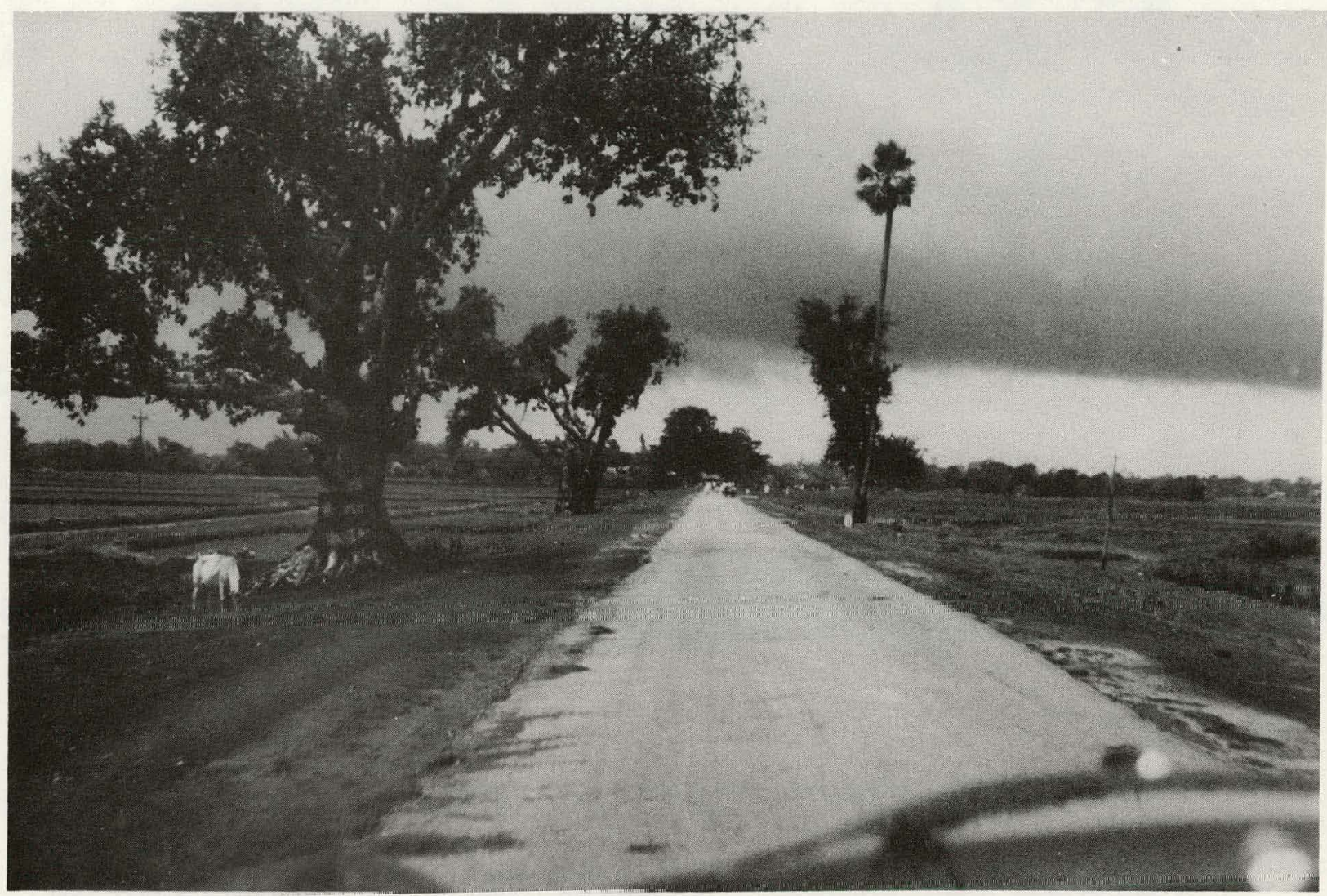

Figure 14. Bands of roll clouds that appeared ahead of a monsoon depression on June 29, 1979. Photograph was taken near Digha. 

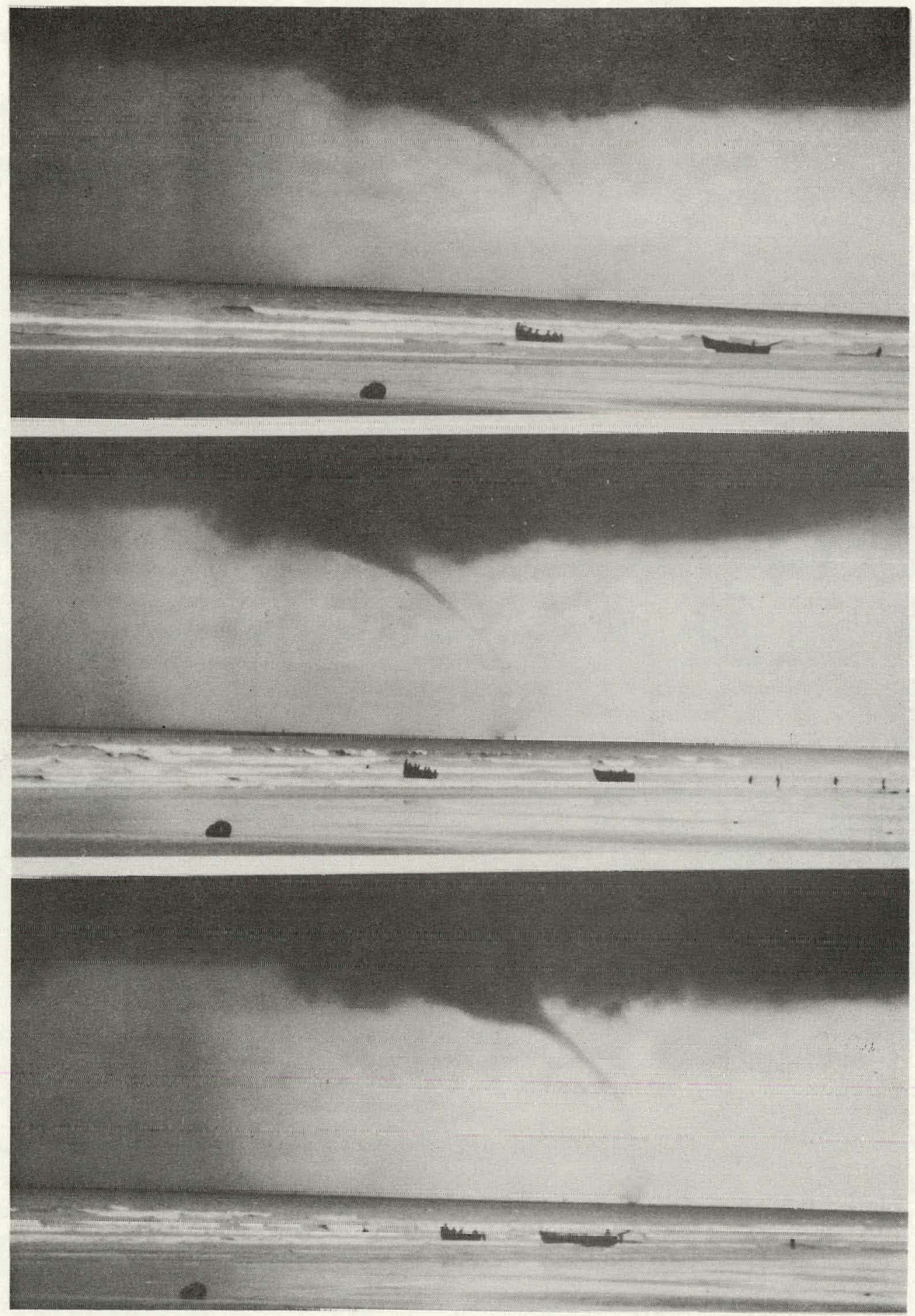

Figure 15. Waterspout over Bay of Bengal about $5 \mathrm{~km}$ from the beach. Photographs were taken successively from top to bottom. 


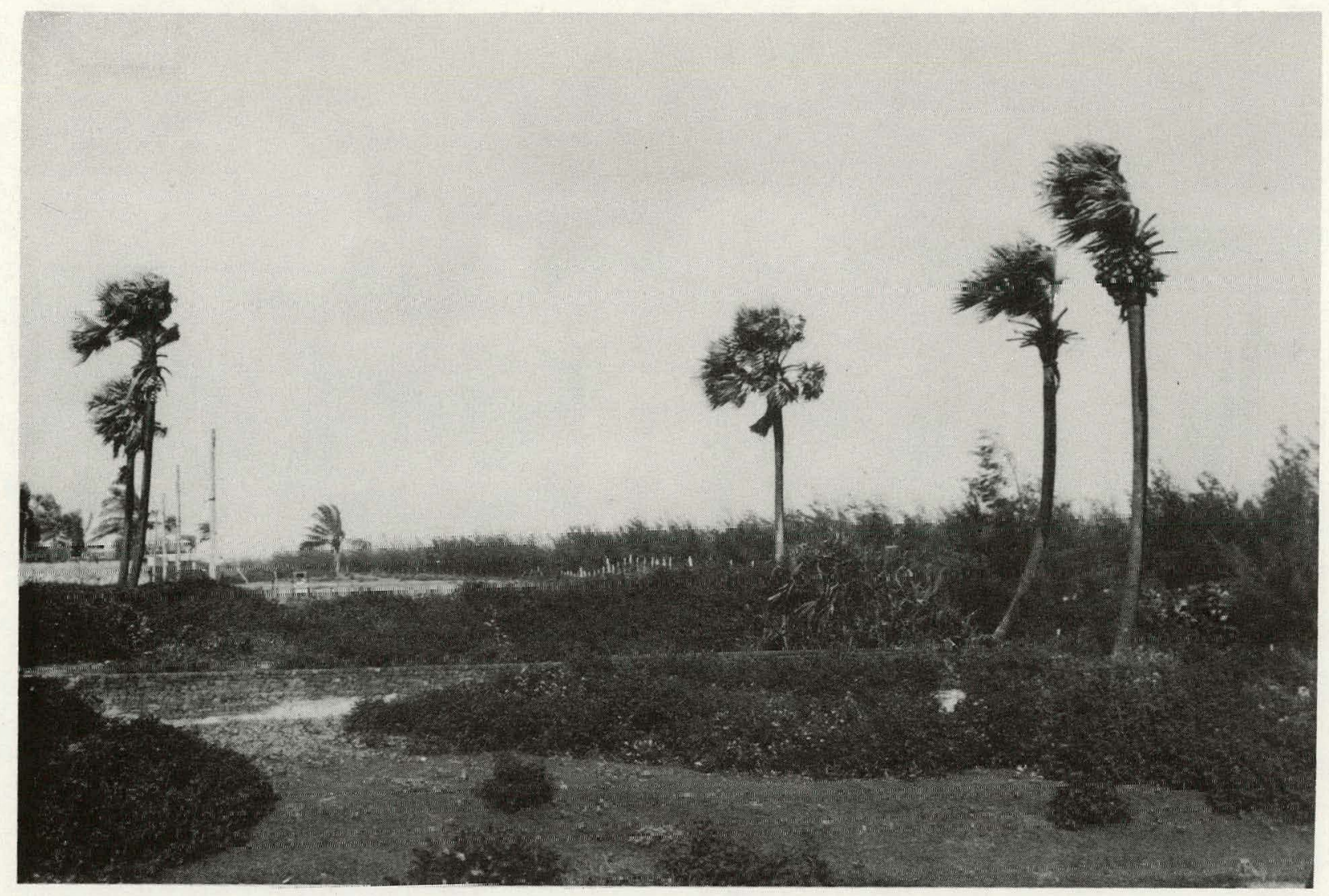

Figure 16. View of a convective cell over Digha. Also note the wind-induced shapes of palm trees.

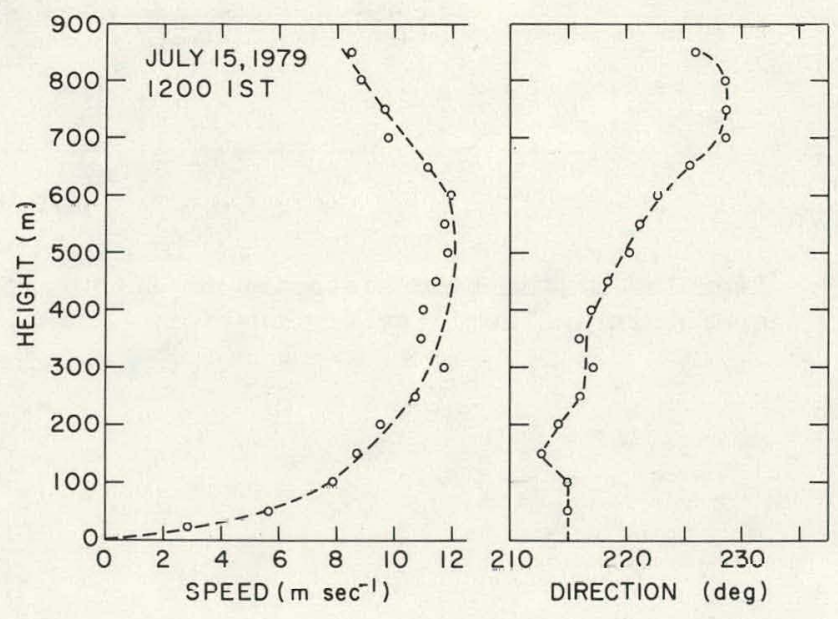

Figure 17. A typical wind speed and direction profile in the planetary boundary layer.

Profiles were derived from pilot balloon sounding. 

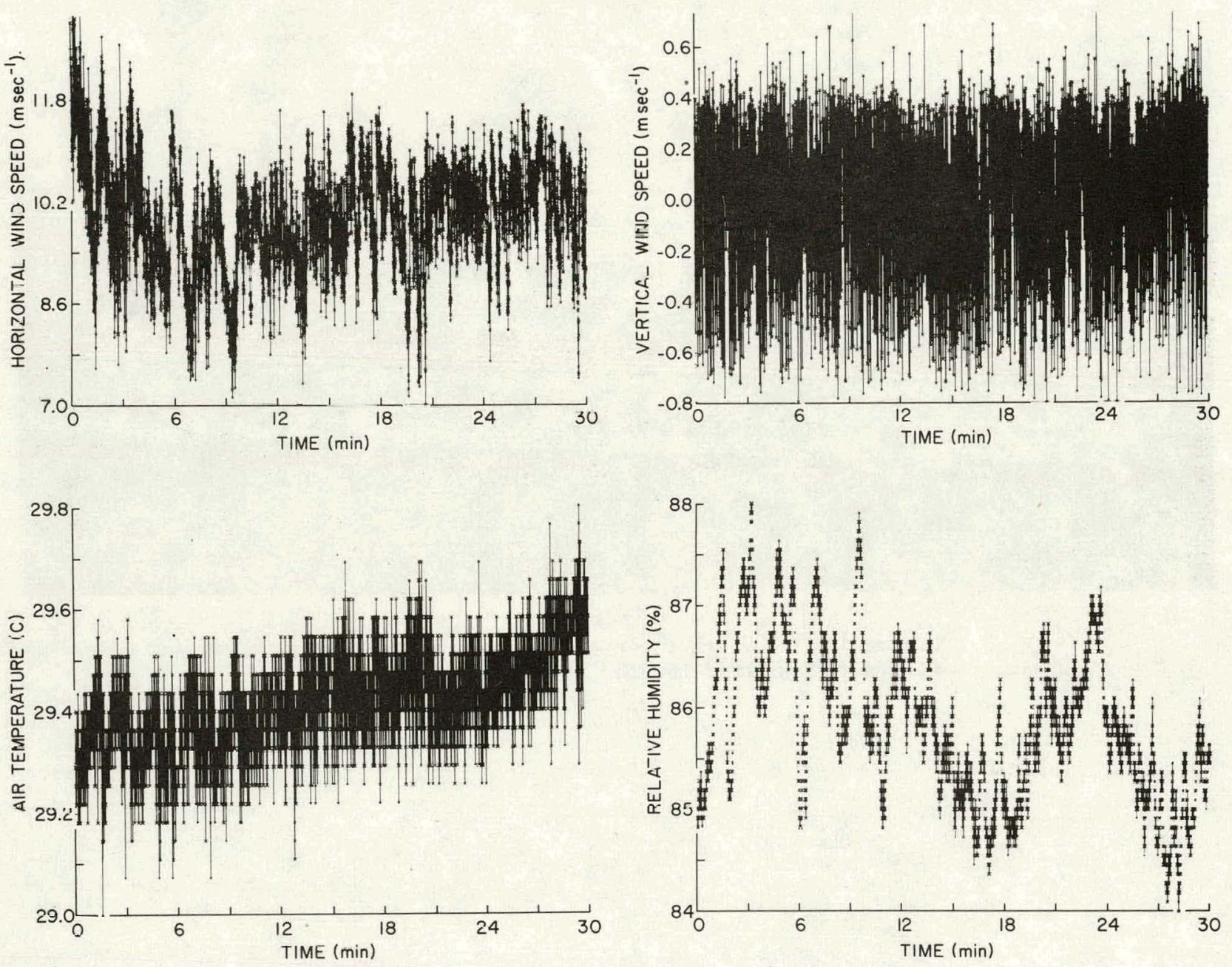

Figure 18. Examples of the time histories of turbulence and temperature and humidity fluclualions. 


\section{ACKNOWLEDGMENTS}

The work was supported by the Global Atmospheric Research Program, Division of Atmospheric Sciences, National Science Foundation, and the U.S. Department of Energy. The authors would like to thank India Meteorological Department, U.S. MONEX Project Office, Mr. D.K. Khan, Digha, and the members of the BNL Atmospheric Sciences Division for the assistance rendered at various stages of this experiment. The authors would like to thank India Meteorological Department for permission to reproduce Figure 3.

\section{REFERENCES}

1. Rao, Y. P., 1976. Southwest Monsoon, Meteorological Monograph, India Meteorological Department.

2. Ramage, C. S., 1971. Monsoon Meteorology, Academic Press, New York, pp. 296.

3. Kotteswaram, P. and George, C. A., 1958. On the formation of monsoon depressions in the Bay of Bengal, Indian J. Meteorol. Geophys. 9, 9-22.

4. Kotteswaram, P. and George, C. A., 1960. A case study of monsoon depression in the Bay of Bengal, in Monsoons of the World, 145-56.

5. Krishnamurti, T. N., Kanamitsu, M., Godbole, R., Chang, C. B., Carr, F., and Chow, J. H., 1975. Study of a monsoon depression, (I) Synoptic Structure, J. Meteorol. Soc. Jpn. 53, 227-40.

6. Krishnamurti, T. N. and Bhalme, H. N., 1976. Oscillations of a monsoon system. Pt. I. Observational aspects, J. Atmos. Sci. 33, 1937-54.

7. Sikka, D. R., 1978. Some aspects of life history, structure and movement of monsoon depressions, in Monsoon Dynamics, Ed. T. N. Krishnamurti, 1501-29.

8. SethuRaman, S., Tuthill, W. A., and McNeil, J., 1978. Instrumentation and data acquisition system for an air-sea interaction buoy, Bull. Am. Meteoro1. Soc. 59, 1102-13.

9. SethuRaman, S. and Tuthill, W. A., 1978. Response characteristics of a new bidirectional vane, Bull. Am. Meteorol. Soc. 59, 1114-18.

10. SethuRaman, S., 1977. The observed generacion and breaking of atmospheric internal gravity waves over ocean, Boundary-Layer Meteoro1. 12, 331-49.

11. Raynor, G. S., SethuRaman, S. and Brown, R. M., 1979. Formation and characteristics of coastal internal boundary layers during onshore flows, Boundary-Layer Meteorol. 16, 487-514. 
12. Golden, J. H., 1974. The life cycle of Florida Keys' waterspouts, J. App1. Meteorol., 13, 676-92.

13. Putnam, P. C., 1948. Power from the wind. Van Nostrand, 223 pp.

14. Wade, J. E. and E. W. Hewson, 1979. Trees as a local climatic wind indicator, J. Appl. Meteorol. 18, 1182-87. 
APPENDIX I

SURFACE. WEATHER MAPS

$-25-$ 


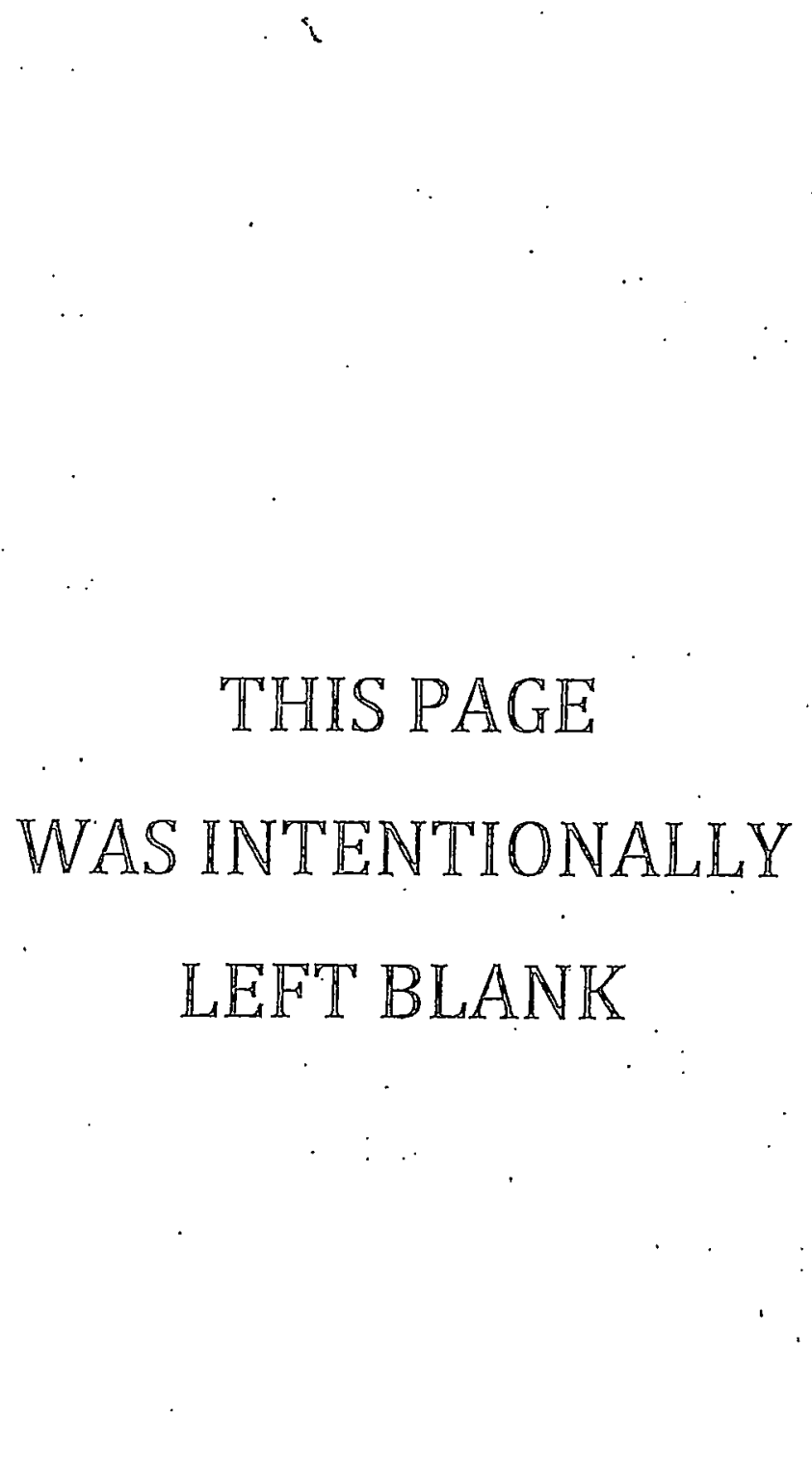



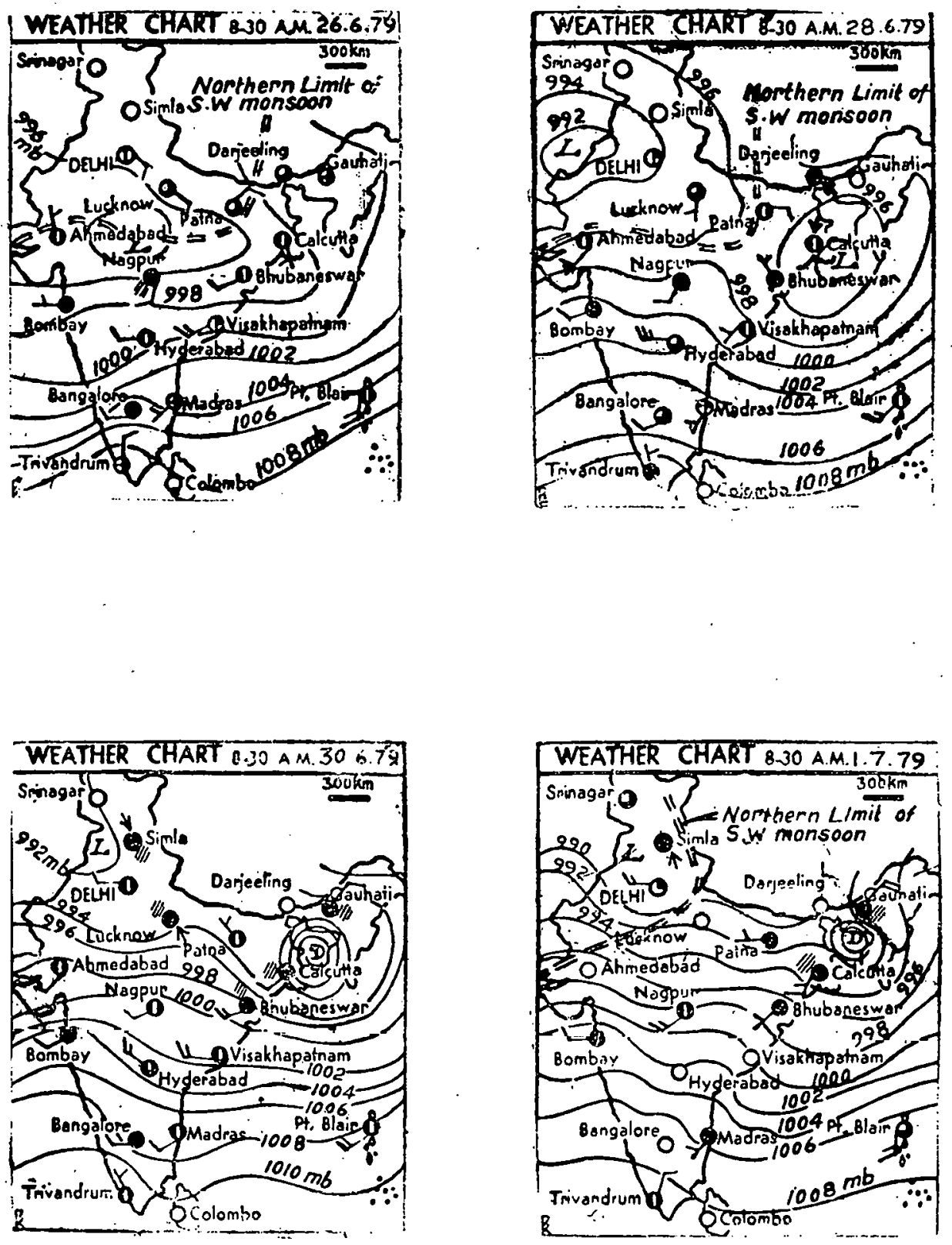

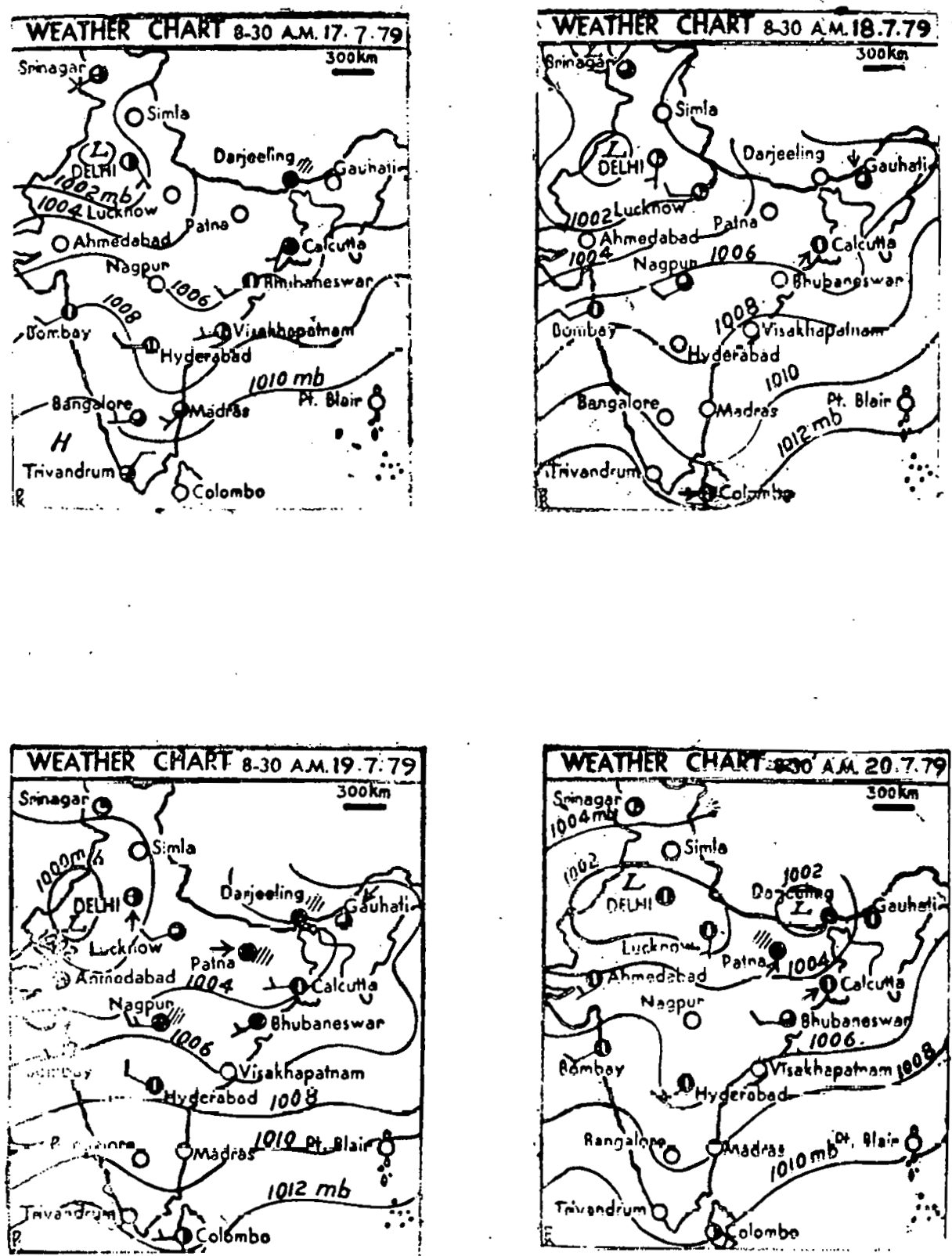

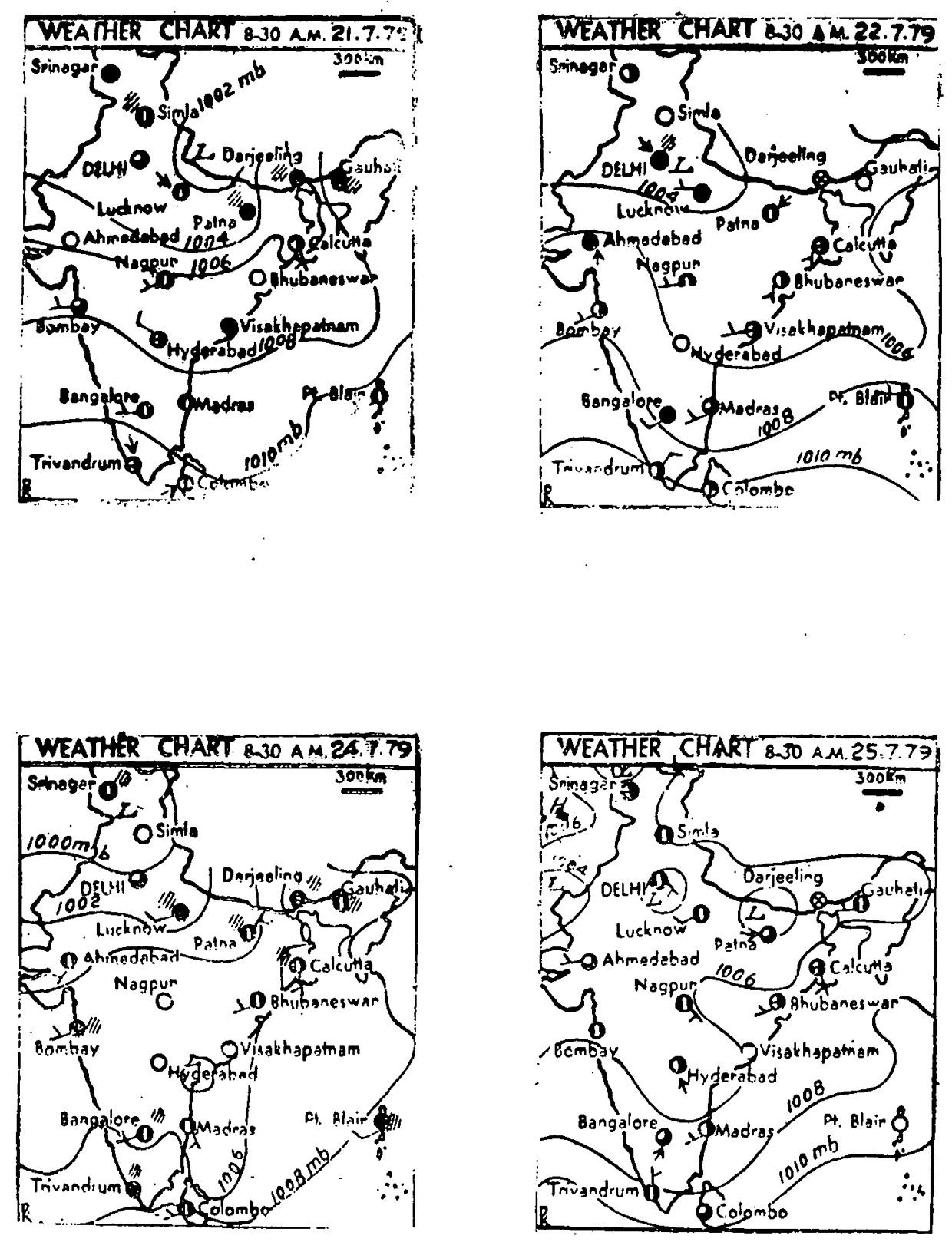

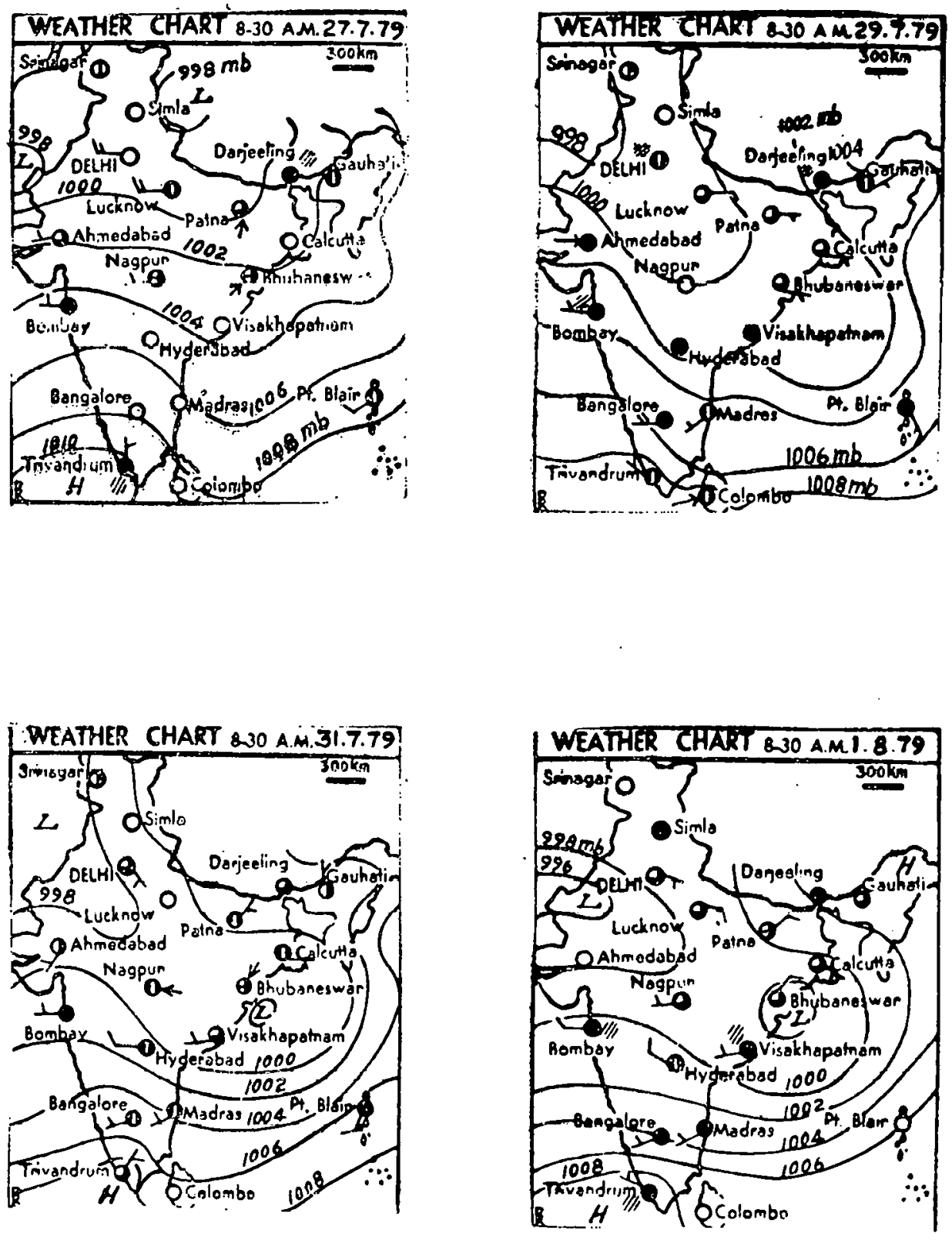

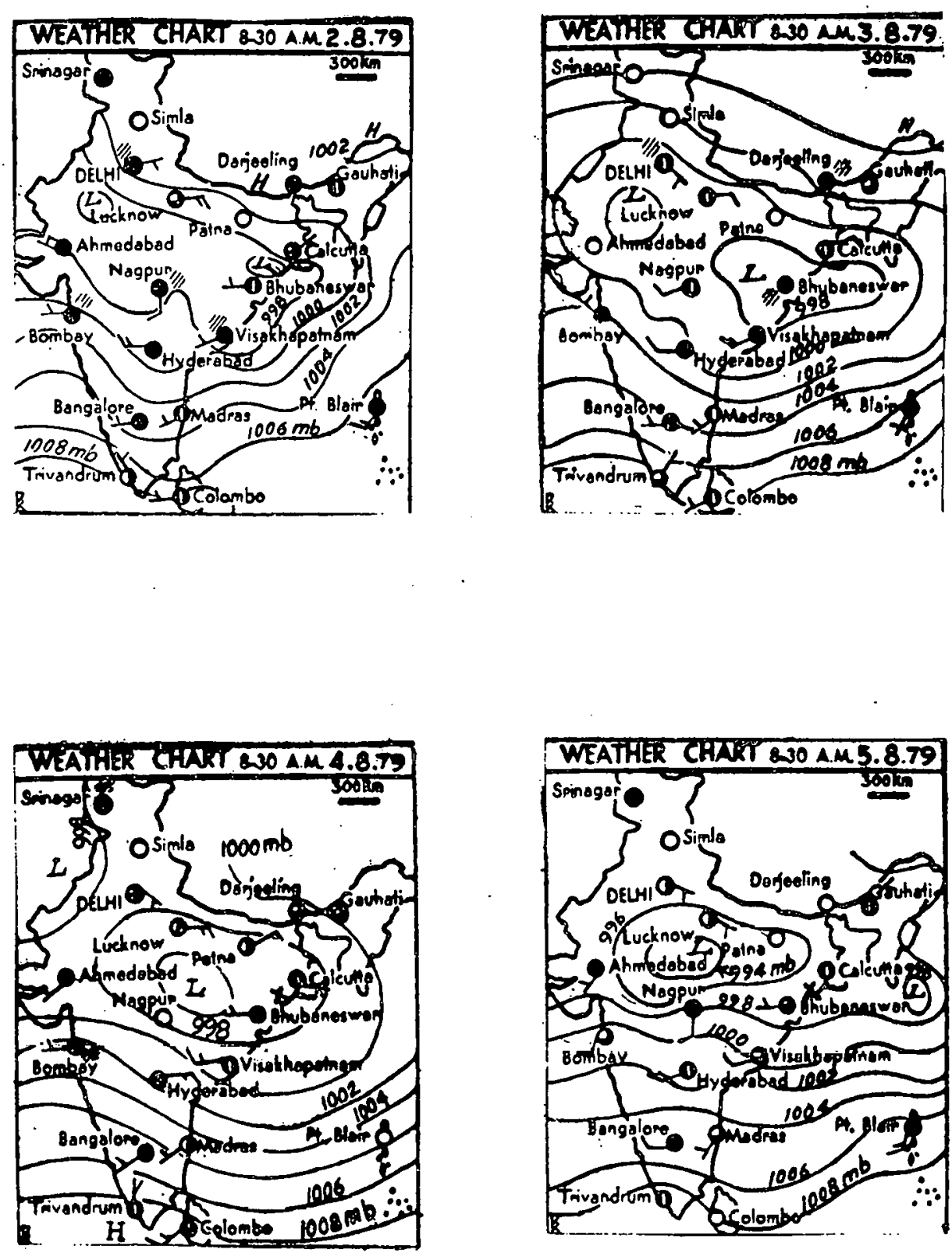

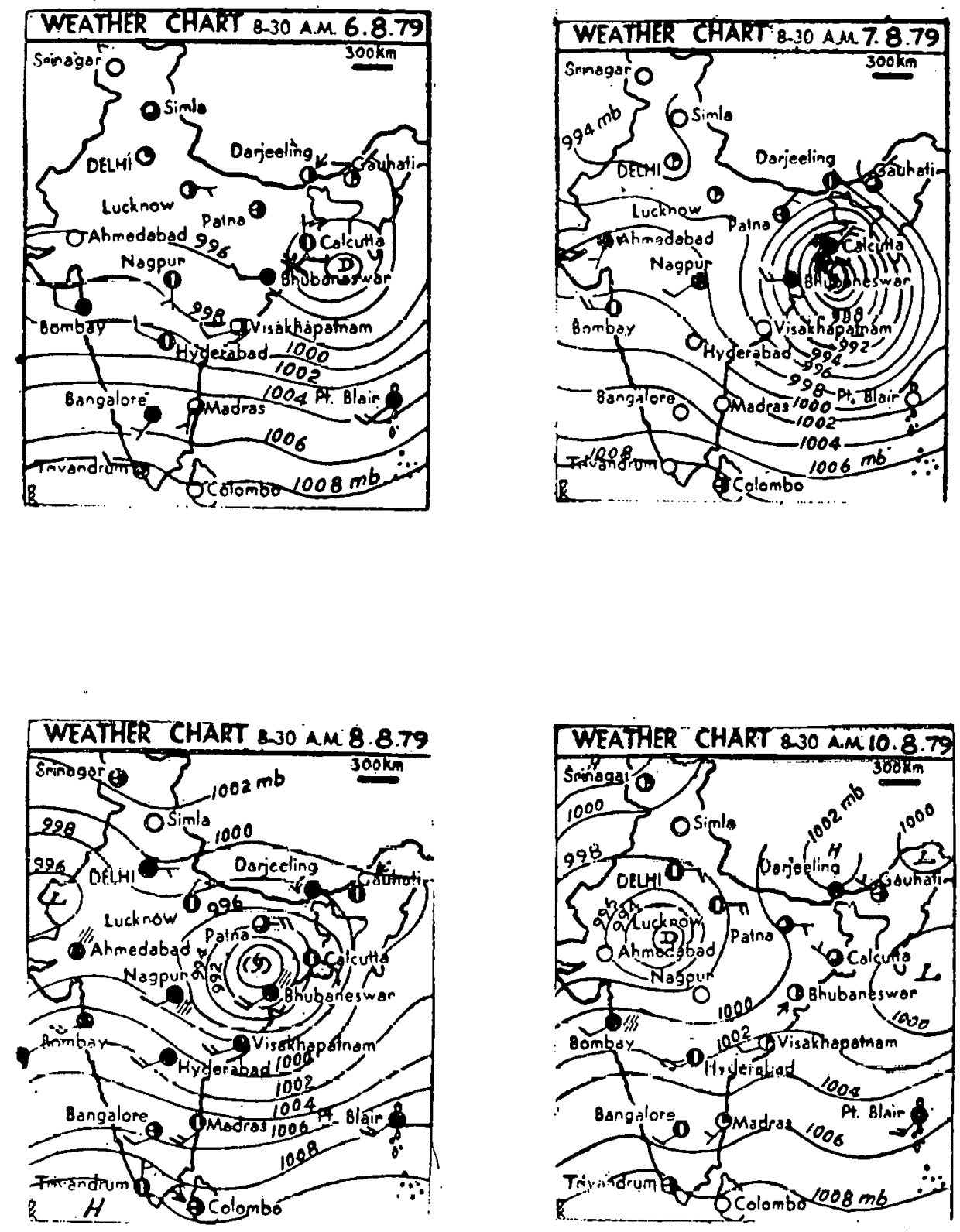

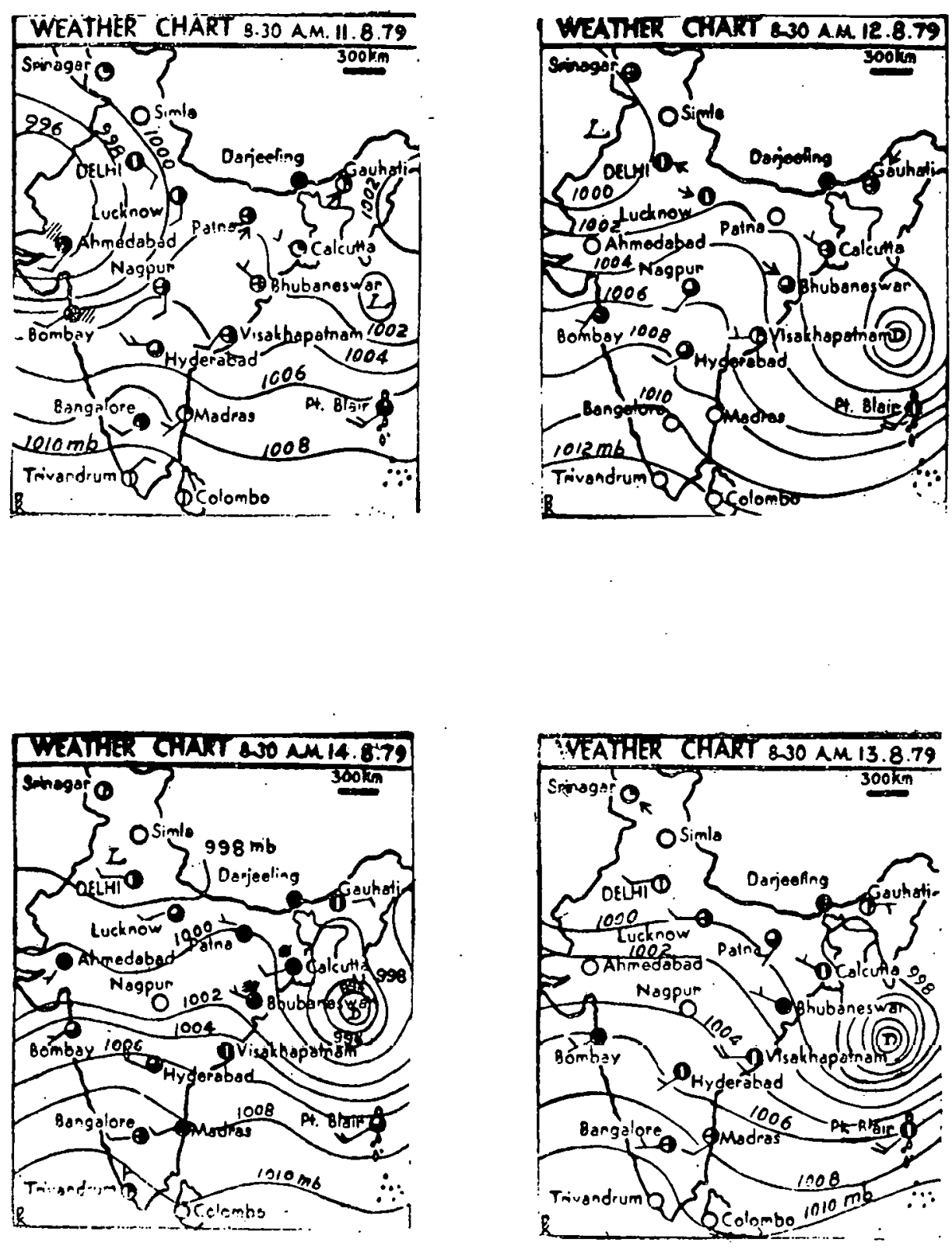